\title{
A SYSTEMATIC REVIEW AND META-ANALYSIS OF WILLINGNESS- TO-PAY VALUES: THE CASE OF MALARIA CONTROL INTERVENTIONS ${ }^{\dagger}$
}

\author{
M. TRAPERO-BERTRAN ${ }^{\mathrm{a}, *}$, H. MISTRY ${ }^{\mathrm{a}, \mathrm{b}}$, J. SHEN $^{\mathrm{c}}$ and J. FOX-RUSHBY ${ }^{\mathrm{a}}$ \\ ${ }^{a}$ Health Economics Research Group, Brunel University, UK \\ ${ }^{\mathrm{b}}$ Health Economics Unit, University of Birmingham, Birmingham, UK \\ ${ }^{\mathrm{c}}$ Institute of Health and Society, Newcastle University, Newcastle upon Tyne, UK
}

\begin{abstract}
The increasing use of willingness to pay (WTP) to value the benefits of malaria control interventions offers a unique opportunity to explore the possibility of estimating a transferable indicator of mean WTP as well as studying differences across studies. As regression estimates from individual WTP studies are often assumed to transfer across populations it also provides an opportunity to question this practice.

Using a qualitative review and meta analytic methods, this article determines what has been studied and how, provides a summary mean WTP by type of intervention, considers how and why WTP estimates vary and advises on future reporting of WTP studies.

WTP has been elicited mostly for insecticide-treated nets, followed by drugs for treatment. Mean WTP, including zeros, is US $\$ 2.79$ for insecticide-treated nets, US\$6.65 for treatment and US\$2.60 for other preventive services. Controlling for a limited number of sample and design effects, results can be transferred to different countries using the value function. The main concerns are the need to account for a broader range of explanators that are study specific and the ability to transfer results into malaria contexts beyond those represented by the data. Future studies need to improve the reporting of WTP. Copyright $\odot 2012$ John Wiley \& Sons, Ltd.
\end{abstract}

Received 23 September 2010; Revised 8 February 2012; Accepted 15 February 2012

KEY WORDS: $\quad$ willingness to pay; malaria; meta-analysis; prevention; treatment; meta-regression

\section{INTRODUCTION}

Malaria can affect diverse features of human existence including health, mobility, investment choices and even fertility (Malaney et al., 2005). Although its endemic and epidemic nature influences many national policies, its spread and effect extends beyond national boundaries thus justifying the development of collective action and international policy.

Both cost-effectiveness and cost-benefit analysis (CBA) have been used or proposed to help make difficult choices about the extent and focus of national and international support for the prevention and treatment of malaria (e.g. Kamya et al., 2002; Mulligan et al., 2006; Breman et al., 2006; Roll Back Malaria Partnership, 2008). As malaria has detrimental health and nonhealth effects that can have important consequences for economic development, CBA is more appropriate theoretically for decision making as it can summarise the monetary value of all benefits (Mills et al., 2008). WTP is the maximum a person or household would be willing to pay for a good or service and is one route for providing an estimate of benefit for use in CBA

\footnotetext{
*Correspondence to: HERG, Brunel University, Uxbridge, Middlesex UB8 3PH, UK. E-mail: marta.trapero-bertran@brunel.ac.uk

${ }^{\dagger}$ Supporting information may be found in the online version of this article.
} 
(Brouwer and Bateman, 2005). Recently, many studies have provided estimates of mean willingness to pay (WTP) for malaria prevention and treatment. A review of these values could help provide estimates of benefit for economic evaluation, predict WTP in a variety of situations using a broader knowledge of its determinants (van Houtven, 2008) and indicate key gaps in existing knowledge (e.g. van Houtven et al., 2007).

Although systematic reviews of effectiveness and cost-effectiveness analysis are common in the health sector, this is not the case with WTP studies, perhaps because of the heterogeneity of research methods and reporting practices (van Houtven, 2008). However, in the environmental field, 'benefit transfer' is used to transfer estimates from data-rich to data-poor settings using unadjusted or adjusted techniques (e.g. Brouwer et al., 1999). Although widely practiced, unadjusted transfer can be hazardous as differences between context (e.g. socioeconomic, service provision, risks) are not accounted for (OECD, 2002). Adjusted techniques include using experts and, index-based calibration exercises using local data on specific determinants and meta-analysis (Bateman et al., 2000). Although meta-analysis/regression is still based on the transfer of a whole function, it allows results from several studies to be used together. This has been shown to be particularly important when contexts are more dissimilar (Brouwer and Bateman, 2005). However, the importance of good quality benefit estimations from original studies to the quality of benefit transfer has also been recognised (Brouwer and Bateman, 2005; Wilson and Hoehn, 2006), and this will also be the case for meta-analyses.

Relative to other health interventions, first, studies on WTP for malaria control interventions have been unusually common (Diener et al., 1998; Olsen and Smith, 2001) and therefore offer a potentially natural route to exploring some issues of practice within health economics. Second, a cursory view of the malaria literature shows that the interval of variation between mean estimates is wide but that the nature of studies (e.g. sample size, area of study, methods of calculating WTP) also vary. WTP studies can be costly and time-consuming to implement and analyse for policy decisions. A synthesis of literature could feed into policy decisions in a variety of contexts and meta-analysis may offer a useful analytical framework as long the quality is reasonable and the basis for comparison is justified.

Our aims in this study were fourfold: first, to find out what is known about WTP for malaria control, that is, what has been studied; second, to calculate summary measures of mean WTP; third, to consider how and why mean WTP varies; and fourth, to reflect on the processes of our evaluation and consider the implications for future reporting of WTP studies for malaria control and other health interventions.

\section{METHODS}

Five databases (MEDLINE, Ingenta, Bath Information and Data Services, International Bibliography of the Social Sciences and Econlit) were searched from their inception to August 2011 using the following key words: (i) willing or willingness and pay crossed with malaria and (ii) contingent and value or valuation with malaria as well as MESH terms and 'wild cards' as appropriate to the database. In addition, an Internet search in Google Scholar was undertaken using the same search terms in English and Spanish. Articles were excluded if they were not WTP studies, used observed rather than stated preferences for WTP, did not contribute information for descriptive or quantitative analysis, were inaccessible, reported WTP for malaria-specific goods that could not be extracted from other services or goods, referred to treatment access or reported duplicated results.

A data extraction form included questions on context (e.g. geographical study location), study question and design (e.g. starting bid values, nature of WTP question; for definitions, see Appendix A), type of good/service valued, sampling and characteristics of sample (e.g. method of sample selection, income level), mean of WTP values and method of analysing WTP (e.g. type of regression model). Each abstract and article selected was double reviewed, with a third reviewer consulted where necessary.

Three types of analyses were undertaken. First, summary descriptive statistics were used to describe the background (e.g. country, level of endemicity) and methods of eliciting WTP. Further quantitative analysis was based on articles reporting mean WTP measures and standard deviations. Second, meta-analysis 
was used to summarise mean WTP. Third, meta-regression was used to explain heterogeneity in mean WTP (Van Houtven, 2008). The quantitative analysis used the mean WTP results provided by the articles, and therefore results from this analysis rely on methods of calculation from each article.

To aid comparative quantitative analysis, we converted mean WTP values to US\$2011 using countryspecific gross domestic product (GDP) deflators (World Bank, IMF, 2006) and World Bank purchasing power parities (Mulligan et al., 2003). Mean WTP values were multiplied by the coefficient of GDP for 2011 divided by the GDP of the particular year of the study and then divided by the purchasing power parity conversion factor for 2011. The advantage of using international dollars is that international and intertemporal distortions in prices are accounted for as an international dollar buys a comparable amount of goods and services across countries over time.

A random effects model was used to conduct the meta-analysis that was based on mean WTP weighted by the inverse of the variance of each included study (Petitti, 2000; Sutton et al., 2004; Sutton and Higgins, 2008). A fixed effects model was not used because included studies differed in design and conduct in many ways, such as the characteristics of the patients or intervention (i.e. dose of drug or vaccine). Mean WTP values are assumed to be randomly distributed with the central point of the distribution the focus of the pooled estimate, with $95 \%$ CIs. The chi-squared test was used to test for evidence of heterogeneity and the $I^{2}$ test undertaken to indicate variation in mean WTP attributable to heterogeneity. The random-effects model used the DerSimonian and Laird (1986) method because of the presence of heterogeneity and was performed in STATA version 10 (StataCorp, 2007). This model assumes a different underlying effect for each study and takes this into consideration as an additional source of variation (Perera and Heneghan, 2008).

Summary valuations from the meta-analyses are grouped by the most frequent types of 'good' [insecticidetreated nets (ITNs), other prevention and treatment goods], survey design characteristics (elicitation format, country and rurality) and reported for the inclusion and exclusion of zero WTP values. ITNs were considered separately because of their similarity and frequency of study.

The presentation of results by ex/inclusion of zero values arose following a finding that some WTP studies excluded zeros from mean values whilst other studies did not state whether they were included or, if they did, how they were accounted for. Zero values should be accounted for, ideally in terms of whether they are 'true' zeros, protest responses or even negative values (Hanley et al., 2009) to ensure that parameter estimates are consistent and any calculated measures of benefit are unbiased (Strazzera et al., 2003). The default position was therefore to assume zeros were included unless otherwise stated. In two instances, information on rurality was missing and this was replaced by the modal setting (i.e. rural).

A random-effect meta-regression is also used to synthesize research findings, to test hypotheses and lead to interpretation for policy in the presence of heterogeneity (Sutton et al., 2004). The random effects meta-regression allows for heterogeneity not explained by the covariates. Mean WTP estimates formed the dependent variable, with the remaining treated as independent explanators of variance. To establish the range of independent variables for inclusion, we undertook an examination of the variables included in each studyspecific regression model with respect to the type and number of variables as well as the level and direction of significance. The criteria used to select independent variables were being the subject of a study in no less than three articles and having a 'reasonably clear' direction of effect across studies. A priori expectations about the signs of coefficients were based on the proportion of studies reporting a particular sign. For example, a positive sign was expected if most articles reported it. However, the sign was considered indeterminate if (i) only one article reported that finding or (ii) the proportion of studies reporting either sign was equal.

Where possible, we used study-specific data directly for each of the selected independent variables (e.g. percentage of males in sample) or by recoding study-specific data (e.g. type of education, to account for different categorisations across publications). However, some data were collected in a way that is either too heterogeneous or was not usable because of insufficient reporting across articles (e.g. income). In some cases alternative data was sought for all studies, for example gross national income (GNI) per capita. Not all articles included in the analysis reported information regarding gender and average number of years in education. 
Missing data were replaced using modal or mean values. Of 89 values for gender, 25 were imputed, and of 89 estimations for education, 24 were replaced.

Two meta-regressions of mean WTP were performed: one for all interventions and one only for ITNs. To avoid double counting, we dropped any estimates from the same study that had not included zero values if an estimate of mean value had also included zero values. Any variable causing multicollinearity was dropped. The regression was weighted by the standard deviation of each study.

The proportion of the between-study variance $\left(\tau^{2}\right)$ of the model with and without covariates was used to determine explained variance of the model, along with the adjusted $R^{2}$ (to measure the proportion of betweenstudy variance explained by the covariates), and a joint test for all covariates to control the risk of false-positive findings. Because some data used were published in different articles but came from the same studies or countries, a sample-weighted least squares meta-regression with clustering was conducted. As with the meta-analysis, metaregressions were estimated for models including and/or excluding zeros. Because the outcome variable was log-transformed, such coefficients can be interpreted as elasticities. Other coefficients were interpreted using the exponential function and correspond to changes in the ratio of the expected geometric means of the original outcome variable. The exponentiated values were compared with the value of one to facilitate comparison.

\section{RESULTS}

\subsection{Articles selected}

Figure 1 documents the flow of articles through the study and the reasons for exclusion. Of 97 abstracts found, 59 met all inclusion criteria for the descriptive analysis, and from those, only 24 could be included in the metaanalysis and meta-regression.

Of the 59 articles reviewed, most were journal articles (85\%), followed by technical reports (10\%). Forty-two percent of published articles were located in social sciences journals and 39\% in medical science journals. Around 41\% were published between 2005 and 2011, with only seven published in the 1990s (see Appendix B). The 59 publications derived from 41 studies. Of the studies from Nigeria, two had six and five publications each, one study from Ethiopia had four publications and five other studies (from India, Ghana, Cameroon, Central African Republic and Tanzania) had two publications each.

\subsection{Background to studies and articles}

Of the 59 articles included, 29\% were from Nigeria, with the remaining articles from other African countries, Burma, India, Indonesia and Sri Lanka. Forty-seven percent of the articles were undertaken in highly malaria endemic areas, $15 \%$ in holoendemic (high levels in early years of life), $2 \%$ in an area of low endemicity, one article in a mix of areas with low and high endemicity and 34\% did not give such information. Fifty-one percent of articles were based on interviews of households in rural areas, $37 \%$ in both rural and urban areas and $12 \%$ not specified.

Four percent of publications interviewed only the household head, whereas $61 \%$ opted for either household head or a household representative. However, 29\% of articles provided no information about whose views were solicited. Most articles (63\%) used randomly selected samples, but only $16 \%$ provided any statistical justification for the sample size used and 23 articles (40\%) did not state the method of sampling. The smallest number of individuals interviewed was in the USA $(n=13)$ and the largest in Burkina Faso $(n=2,490)$, with articles having a median of 329 people. With respect to characterising the reporting of samples, almost half did not contain the mean age of respondents, $61 \%$ did not give mean household income and $35 \%$ did not report gender.

The main study question covered a wide range of justifications for research, including the following: interest in assessing the WTP for a malaria good and/or service and factors affecting it; socioeconomic differences in preferences and WTP; comparison of WTP with 'ability' to pay (assessed from current household expenditure); validity of different elicitations methods to calculate WTP estimates; equity and inequity implications of WTP; setting priorities; studying demand and policy implications for malaria goods and/or services; to study the acceptability and preference for malaria treatment and prevention; to study new approaches to benefit transfer; 


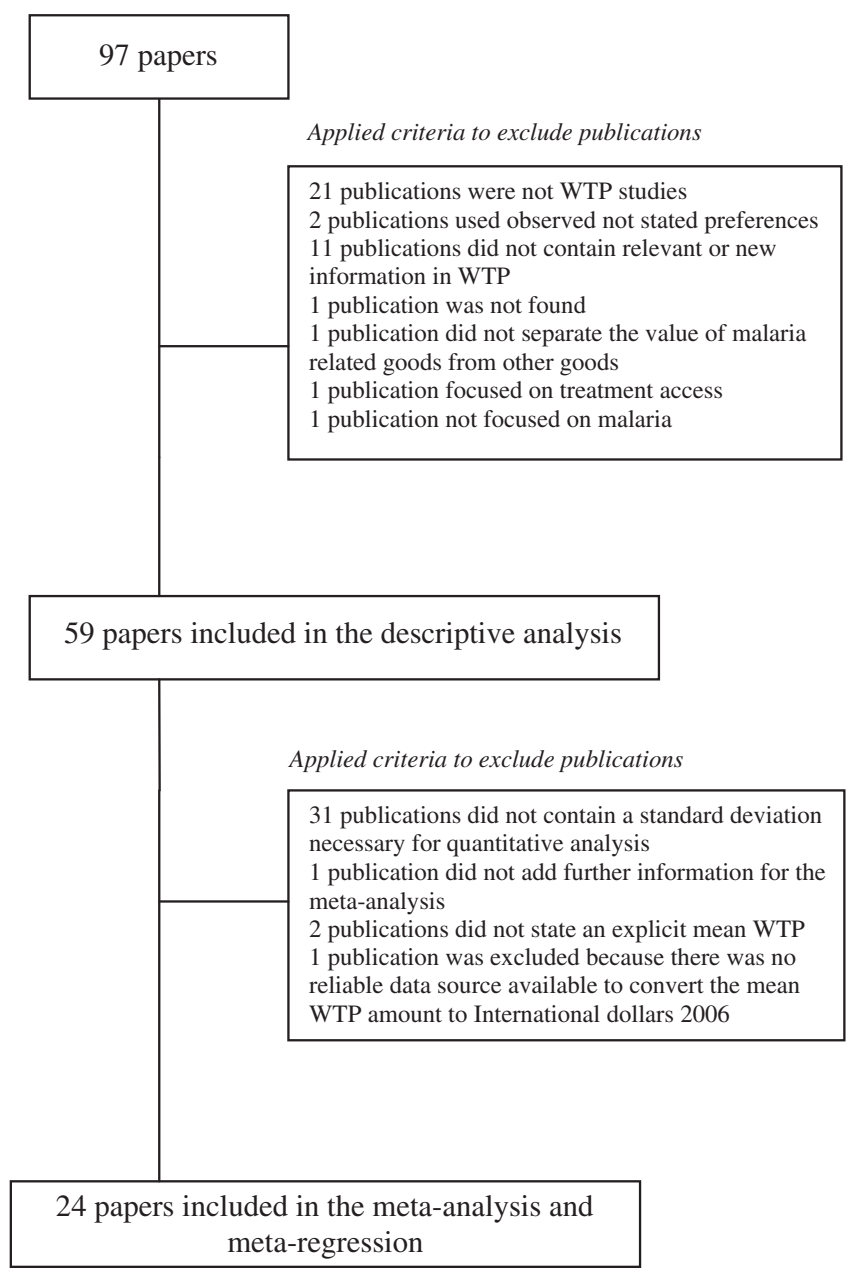

Figure 1. Screening and selection method of the articles

to assess the economic burden of malaria; to promote malaria goods and/or services; and how to implement a malaria prevention program.

\subsection{Methods of eliciting WTP}

Appendix B specifies the elicitation format(s) used in each study and shows that six question formats were used to elicit WTP (for definitions, see Appendix A) plus 15 articles (25\%) did not specify their approach. The most frequently used method was the bidding game (BG; 63\%), used singly or combined with another method. This was followed by the single-bounded dichotomous choice (SBDC), SBDC with open-ended method (SBDC + OE) and open-ended questions (OEs). The lowest starting bid was offered in Burma for a test kit (US\$1.004) and the highest starting bid in Ghana for treatment of malaria (US\$50.31). Ninety-four percent of articles did not provide the percentage of 'do not know' responses, and it is not clear whether most studies provided this option to respondents.

Three studies (covering twelve articles) tested the effects of different elicitation formats and found statistically significantly effects on stated WTP, with open-ended formats producing lower estimates than the BG and SBDC + OE.

\subsection{Meta-analysis: mean WTP values}

There was often more than one mean WTP estimate per publication, as researchers asked about different goods, different populations and used more than one approach to ask WTP questions. In fact, 53\% of publications had 
four or more mean estimates. Twenty-four of 59 articles from 14 studies provided 104 observations of mean WTP, including and excluding zeros, for the meta-analysis. Six articles did not clarify whether zeros were included (Wiseman et al., 2005; Onwujekwe et al., 2005a, 2005c; Ofiara and Allison, 1986; Jimoh et al., 2007; Legesse et al., 2007), and two articles did not state whether the area was rural or urban (Onwujekwe et al., 2004c; Wiseman et al., 2005).

Table I categorises three main types of goods and reports the results of the meta-analyses. For the type of good valued, 69 of 104 estimates included zero values, of which 53\% focused on ITNs and a further $36 \%$ on other forms of prevention. Average WTP was highest for treatment, followed by ITNs and other prevention goods/services. However, WTP for treatment (including zeros) has a large 95\% CI and a long right hand tail compared with the others. It is also notable that $80 \%$ of articles did not reveal the percentage of nonresponse.

Table I. Results from the random-effects meta-analysis (US\$ 2011)

\begin{tabular}{|c|c|c|c|c|c|}
\hline & Zeros included? & Mean WTP & Lower $95 \%$ CI & Upper 95\% CI & $\mathrm{N}$ \\
\hline \multicolumn{6}{|l|}{ Type of good } \\
\hline \multirow[t]{2}{*}{$\mathrm{ITNs}^{\mathrm{a}}$} & Yes & $2.79 * * *$ & 1.07 & 4.51 & 34 \\
\hline & No & $6.90 * * *$ & 6.20 & 7.60 & 13 \\
\hline \multirow[t]{2}{*}{ Other prevention } & Yes & $2.60 * * *$ & 2.44 & 2.75 & 26 \\
\hline & No & $4.82 * * *$ & 4.12 & 5.51 & 6 \\
\hline \multirow[t]{2}{*}{ Treatment } & Yes & $6.65^{* * *}$ & 4.42 & 8.88 & 9 \\
\hline & No & 5.82 & 4.74 & 6.90 & 16 \\
\hline \multirow[t]{2}{*}{ Overall WTP for malaria goods/services } & Yes & $5.25 * * *$ & 4.30 & 6.20 & 69 \\
\hline & No & $6.57 * * *$ & 5.84 & 7.31 & 35 \\
\hline \multicolumn{6}{|l|}{ Elicitation format } \\
\hline \multirow[t]{2}{*}{ BG } & Yes & $2.79 * * *$ & 2.28 & 3.30 & 27 \\
\hline & No & $5.61 * * *$ & 4.68 & 6.55 & 24 \\
\hline \multirow[t]{2}{*}{$\mathrm{SBDC}+\mathrm{OE}$} & Yes & $3.10 * * *$ & -0.16 & 6.40 & 10 \\
\hline & No & $6.18 * * *$ & 4.61 & 7.74 & 4 \\
\hline SH & Yes & $3.62 * * *$ & 2.31 & 4.93 & 7 \\
\hline $\mathrm{OE}$ & Yes & $0.81 * * *$ & 0.70 & 0.92 & 10 \\
\hline SBDC & Yes & $28.68 * * *$ & 18.38 & 38.98 & 6 \\
\hline \multirow{2}{*}{ Payment card } & Yes & $58.73 * * *$ & 20.14 & 97.31 & 7 \\
\hline & No & 1.14 & 1.11 & 1.17 & 1 \\
\hline \multirow[t]{2}{*}{ Not specified } & Yes & $22.80 * * *$ & -17.37 & 62.97 & 2 \\
\hline & No & $12.02 * * *$ & 9.75 & 14.28 & 6 \\
\hline \multicolumn{6}{|l|}{ Country } \\
\hline \multirow[t]{2}{*}{ India } & Yes & $4.52 * * *$ & 3.97 & 5.07 & 4 \\
\hline & No & 6.32 & 6.17 & 6.48 & 1 \\
\hline \multirow[t]{2}{*}{ Cameroon } & Yes & 1.11 & 1.07 & 1.15 & 1 \\
\hline & No & 1.14 & 1.11 & 1.17 & 1 \\
\hline Ethiopia & Yes & 0.62 & 0.60 & 0.64 & 1 \\
\hline \multirow[t]{2}{*}{ Nigeria } & Yes & $3.40 * * *$ & 3.22 & 3.58 & 45 \\
\hline & No & $5.75 * * *$ & 4.81 & 6.69 & 31 \\
\hline \multirow[t]{2}{*}{ Sri Lanka } & Yes & $22.80 * * *$ & -17.37 & 62.97 & 2 \\
\hline & No & $25.40 * * *$ & -19.59 & 70.39 & 2 \\
\hline Sudan & Yes & $2.74 * * *$ & 2.08 & 3.40 & 4 \\
\hline Tanzania & Yes & $2.71 * * *$ & -1.98 & 7.39 & 6 \\
\hline USA & Yes & 67.70 & 38.01 & 97.39 & 6 \\
\hline \multicolumn{6}{|l|}{ Area } \\
\hline \multirow[t]{2}{*}{ Rural } & Yes & $3.89 * * *$ & 1.99 & 5.79 & 33 \\
\hline & No & $7.94 * * *$ & 6.74 & 9.14 & 26 \\
\hline \multirow[t]{2}{*}{ Rural or urban } & Yes & $5.03 * * *$ & 4.76 & 5.29 & 21 \\
\hline & No & $1.06 * * *$ & 0.81 & 1.31 & 9 \\
\hline Not specified & Yes & $2.78 * * *$ & 2.13 & 3.42 & 15 \\
\hline
\end{tabular}

${ }^{a}$ Although ITNs is a preventive measure, it was treated separately because of the quantity of observations.

***Heterogeneity chi-squared test: $p \leq 0.01$. 
Of the 14 different malaria goods or services described by the articles (see Appendix B), 43\% articles were focused on ITNs and 23\% on treatment (see Table I), with the rest (34\%) on a variety of prevention methods, including vaccine for 1 year coverage, retreatment of nets, indoor spraying, larviciding, preventive care, malaria control/eradication and insecticide. Treatment goods included drugs either monotherapy or combined drugs as well as insurance for treatment. Fuller details of the goods and services valued are given in Appendix B. Although some of the products asked about are purchasable on the open market in some form (e.g. untreated mosquito nets, malaria tablets), we noted that $72 \%$ of articles gave no indication of either the market price of the good or service or the price of it is closest competitor (e.g. untreated mosquito nets, if treated mosquito nets were valued).

Regarding elicitation methods, when WTP values include zeros, the payment card, with data from seven studies, had the highest mean WTP (US\$58.7) and largest variation in values both absolutely and proportionally. This was followed by the SBDC format (US\$28.7, $n=6$ ). The $95 \%$ CIs from these methods did not overlap with the next bunching of elicitation methods [BG, structured haggling (SH), SBDC and OE] whose mean WTP ranged between US\$2.79 and US\$6.18. The lowest mean WTP was for the OE format (mean $=$ US $\$ 0.81$, $95 \% \mathrm{CI}=0.70-0.92, n=10$ ), and the $95 \% \mathrm{CI}$ did not cross those of other methods, apart from those studies not specifying the elicitation method, which included a negative lower $95 \% \mathrm{CI}$.

People in rural or urban areas have a higher WTP, when including zero values, than those in rural areas only, and there are marked variations in mean WTP by country. For example, when including zeros, Ethiopia has the lowest mean WTP (US\$0.6) and Sri Lanka has the highest mean WTP (US\$22.8). Mean WTP in Nigeria, which supplied more than $50 \%$ of estimates, was US $\$ 3.4(95 \%$ CI $=3.2-3.6)$.

Table I shows that there are four instances where including zero values indicates that the average mean WTP is higher than when zero values are excluded. One is for mean WTP by treatment, which relies on assumptions about whether zero values are included in nine observations from four studies. However, if the base case was changed to assume that these studies had included zeros, the finding did not change. The second two cases are for payment card and unspecified elicitation format, which relies on assumptions for two studies each. This appears to occur because observations exclude zero values from more studies than include them, although it is clear that the same studies do maintain the correct ordering of values with and without zero values. The fourth instance occurs for 'rural and urban' in the 'area' variable, which relies on assumptions for four observations from two studies. In this case, if the base case had assumed that these studies had included zeros, the incoherence disappears. Table I also shows that some 95\% CIs contain negative values. Although they appear for only one elicitation format, all belong to four different studies, three conducted in Tanzania and one in Sri Lanka. This may have occurred because of skewness, suggesting log transformation could be useful.

\subsection{Meta-regression: explaining variation in WTP}

Appendix C summarises the results from published regression models and shows that nine variables most often explain variation in mean WTP for goods/services to control malaria. ${ }^{1}$ The main findings, in a rough order of strength of evidence, are given as follows:

1) Socioeconomic status: of 20 coefficients from 6 publications, all 18 statistically significant coefficients show a positive relationship between status and WTP.

2) Gender: of 33 coefficients from 20 articles, 14 of 17 were statistically significant coefficients and indicate a positive relationship between being male and having a higher WTP.

3) Marital status: of 29 coefficients from 19 articles, 5 of 7 statistically significant coefficients are negative, indicating being married is associated with a reduced WTP.

\footnotetext{
${ }^{1}$ This exercise was repeated for other prevention goods or services, ITNs and treatment separately, and most of the results were confirmed.
} 
4) Education: of the 30 coefficients from 17 publications, 12 of 15 statistically significant coefficients indicate that more years of education are associated with a higher WTP.

5) Age: of the 28 coefficients from 16 articles, all 11 statistically significant coefficients indicate older people are associated with a lower WTP.

6) Household size: of the 27 coefficients from 13 articles, 10 of the 13 statistically significant coefficients indicate that household size is associated with a higher WTP.

7) Status in household: of the 17 coefficients from 10 articles, 4 of the 7 statistically significant coefficients indicate a positive relationship between being the head of household and WTP.

8) Recent experience of malaria: of the 16 coefficient from 10 articles, 4 of the 7 statistically significant coefficients indicated having malaria was associated with a reduced WTP.

9) Occupation: of 14 coefficients from 7 different publications, 2 of the 4 statistically significant coefficients show a positive relationship between occupation and WTP.

10) Household income and average annual expenditures (proxy for income): of the 7 coefficients from 6 publications, all statistically significant coefficients indicate that there is a positive correlation with WTP.

11) Expenditure to treat malaria: of the 10 coefficients from 6 articles, 3 of 4 statistically significant coefficients showed a positive relationship with WTP.

As the direction of significance was not conclusive for occupation, recent experience of malaria or status in household, these variables were not included in the meta-regression. Because of insufficient information from individual articles, it was also not possible to incorporate data on gender, marital status, age, household size, household income and expenditure to treat malaria in the meta-regression. However, GNI per capita was used as a proxy for household income. As endemicity of malaria could be an explanator of WTP (Onwujekwe, 2004) but is rarely reported by studies, data on malaria incidence were collected separately (World Bank, UNICEF, 2005; Korenromp, 2005).

Table II provides the base and reduced model of the meta-regression of log mean WTP for all interventions valued. It uses a sample of 101 values ( 3 values were dropped to avoid double counting, and both gender and incidence were dropped because of multicollinearity). Model diagnostics show that most variation is due to heterogeneity and that approximately $70 \%$ is explained.

The reduced model in Table II shows that WTP for ITNs is statistically significantly higher than for other prevention goods and that although WTP for treatment is higher than for ITNs, this is not statistically significant. Mean WTP for other prevention goods in general is $67 \%$ lower than for ITNs. The reduced model also shows that compared with the BG, WTP values elicited using open-ended elicitation were statistically significantly lower (at 1\% level), and SBDC was statistically significantly higher (at 10\% level). Log GNI is statistically significantly and positively related to mean WTP, with a $1 \%$ increase in GNI associated with a $1.47 \%$ increase in mean WTP.

In the random effects meta-regression (reduced model) of mean WTP for ITNs, mean WTP values are less (57\% lower) for the OEs compared with the BG method. In this case, including zero values was also statistically significant and negatively related to mean WTP.

\section{DISCUSSION}

This article is a rare attempt in health economics to compare WTP results across goods/services and the first to do so for the prevention and treatment of malaria. The discussion sets out what values have been elicited to date and what is known about their variation. It then considers how reliable and useful these values are before considering how estimates could be improved in the future.

Most articles (64\%) have focused on the WTP for a single intervention rather than several single interventions. However, $36 \%$ of studies did ask for the WTP for more than one intervention and $83 \%$ of studies sought more than one value. WTP has mainly been used to estimate the value attributed to ITNs, followed 
META-ANALYSIS OF WTP FOR MALARIA CONTROL

Table II. Results from meta-regression for all malaria control interventions

\begin{tabular}{|c|c|c|}
\hline \multirow[b]{2}{*}{ Explanatory variable } & \multicolumn{2}{|c|}{ Dependent variable: LMEAN_WTP } \\
\hline & Base model & Reduced model \\
\hline \multicolumn{3}{|l|}{ Prevention for malaria control } \\
\hline ITNs & Base case & Base case \\
\hline Other prevention & $-1.19(0.26)^{* * *}$ & $-1.09(0.25)^{* * *}$ \\
\hline Treatment & $0.21(0.30)$ & $0.29(0.27)$ \\
\hline \multicolumn{3}{|l|}{ Elicitation format } \\
\hline BG method & Base case & Base case \\
\hline SBDC + OE method & $-0.15(0.32)$ & $-0.14(0.31)$ \\
\hline SH value method & $-0.04(0.42)$ & $-0.24(0.38)$ \\
\hline OE method & $-1.76(0.38)^{* * *}$ & $-1.70(0.33)^{* * *}$ \\
\hline SBDC method & $0.86(0.52)$ & $0.84(0.5)^{*}$ \\
\hline Payment card & $-0.94(7.00)$ & $-0.18(0.66)$ \\
\hline Unspecified/unspecific method & $0.19(0.31)$ & $0.14(0.30)$ \\
\hline \multicolumn{3}{|l|}{ Area $\mathrm{T}-\mathrm{T}$} \\
\hline Rural & Base case & - \\
\hline Rural or urban & $0.07(0.29)$ & \\
\hline Unspecified as rural/urban & $-0.47(0.35)$ & \\
\hline Mean WTP including zero values & $-0.19(0.30)$ & - \\
\hline Log GNI payment card & $1.26(0.50)^{* *}$ & $1.47(0.46)^{* * *}$ \\
\hline Log mean years education & $0.12(0.33)$ & - \\
\hline Study conducted in Nigeria & $0.29(0.30)$ & - \\
\hline Constant & $0.18(0.70)$ & $0.20(0.42)$ \\
\hline$N$ & 101 & 101 \\
\hline$\tau^{2}$ & 0.75 & 0.78 \\
\hline$I^{2}$ residual & $99.35 \%$ & $99.68 \%$ \\
\hline Adjusted $R^{2}$ & $47.71 \%$ & $44.79 \%$ \\
\hline
\end{tabular}

Significance of parameters: $* \leq 0.10 ; * * \leq 0.05 ; * * * \leq 0.01$.

by drugs (as monotherapy and combination therapy), a hypothetical vaccine and a retreatment of nets. No study has compared the WTP for different types of prevention with treatment, and therefore this article is the first to do so. The WTP estimates tend to be focused on newer rather than existing methods for controlling malaria, except in the case of ITNs where more estimates exist for those that require annual retreatment. No values have been provided for prevention methods such as sheets, screens or repellents, possibly because these are more readily available in local markets. However, neither have values been elicited for government-provided environmental or biological control or for different approaches to spraying in terms of choice of chemical or focus of spraying. articles did not tend to provide many details about the interventions valued. Therefore, no further analysis could be conducted on variation in definitions of interventions.

The results from the meta-regression (reduced model) show that mean WTP for ITNs is US\$1.03 under the following conditions: when a BG is used to elicit values, when zero values are included, a mean of 3.59 years of education and a mean GNI/capita of 2.23. Under the same conditions, the mean WTP for malaria treatment would be US\$0.91, and the mean WTP for other preventive services would be US\$0.82.

The reliability and validity of these results can be judged in several ways. First, the explanatory variables reflect expected associations and have enabled inclusion of variables that are often not considered within one study, such as a broad range of elicitation mechanisms and types of goods. For example, GNI/capita is statistically significant and positive and reflect findings from the qualitative review of WTP studies. The method of eliciting WTP values is also significantly related to WTP values, with open-ended valuation methods providing consistently lower values than BG approaches and SBDC providing consistently higher values. These correspond with findings reported elsewhere (Yeung et al., 2006; Brouwer et al., 1999) but do indicate that elicitation effects may also extend to interventions with more defined property rights. Second, the regression diagnostics indicate that the proportion of between-study variance is high, the $R^{2}$ is high $(45 \%)$ and the remaining between-study variance appears small at 0.78 . In addition, the overall model $p$ value $(0.000)$ is small, 
and therefore there is evidence for an association of the covariates with the outcome. Finally, three of the individual studies reviewed unusually included an assessment of criterion validity (Onwujekwe, 2004; Onwujekwe, 2001; Bhatia and Fox-Rushby, 2002), and although we cannot transfer the findings to the combined sample, it is interesting to reflect the two main findings: predictions of (non)purchase from stated preferences were correct in $70 \%$ to $85 \%$ of cases, but no significant difference was found between elicitation methods studies (BG, $\mathrm{SH}$ and $\mathrm{SBCH}+\mathrm{OE}$ ).

Although there are good indications that the meta-regression performed as expected, concerns about validity could remain for three reasons. First, the qualitative review indicated the importance of several explanatory variables in individual studies that could not be included because of a lack of reported data (socioeconomic status, wealth, marital status, facing price of intervention and household size). Nevertheless, Brouwer and Bateman (2005) recently concluded that although such variables may be the best fit for individual studies, addition of variables beyond key economic explanators such as income and own/cross price may reduce the transferability of WTP values. Second, although some explanatory data such as income were included, the data used were not study specific, that is, GNI/capita was a proxy for average income in a study site. This is most likely to affect data from countries with several studies as no distinction could be made between different studies, other than by year. Nevertheless, the advantage of the income data used was that it was not subject to differential measurement error likely to arise in studies that choose to measure income differently. One implication of these concerns could be that existing variables overexplain existing variation and are not as important as would first appear. Third, most malaria control interventions exhibit strong positive external effects (use of both preventions and treatment can reduce risk of infection for others), and therefore if WTP of individuals only reflects personal benefits it is likely to substantially underestimate the true value to society of the intervention and therefore bias the value of these estimates for calculating a rate of return for the interventions.

It would be possible to use each mean WTP estimate within calculations of the internal rate of return for investment in ITNs, other preventive interventions or treatment for malaria control in a variety of countries. This is likely to be most useful for decisions comparing malaria control with other health or nonhealth investments. It could also help in comparing the value of investing in the three different categories of malaria control considered. However, it will not help decisions about the efficiency of specific ITNs or specific treatment. Future analysts would have to consider how the range of interventions falling in each of the three categories reflects the nature of goods/services to be evaluated.

It is important to consider generalisability across geographical settings. Data for the meta-regression included estimates from eight countries-from sub-Saharan Africa, India and the USA. However, 17 of 24 articles (corresponding to 79 of 104 estimates) included were from the same region of Nigeria, although the meta-regression showed Nigeria was not a significant explanator itself. There is a lack of evidence from malaria endemic regions such as Latin America, the Middle East, China and South East Asia. Results are likely to be more reliable when more closely related to the context of the included studies rather than stretched way beyond the sample of evidence, although this itself should be tested in the future.

It is also important to consider the usefulness of these results in the context of alternative approaches to the transfer of mean values or whole value functions. Differences in mean WTP for malaria control interventions between the meta-analysis and the meta-regression highlighted the presence of heterogeneity and the importance of controlling for such differences before the transfer of mean WTP values, which would in this instance be better achieved through meta-regression. Brouwer and Bateman (2005) considered benefit transfer from individual studies and showed that mean value transfer is likely to be more reliable in similar situations but that value function transfers were more reliable when transferring across dissimilar contexts. Taking forward such conclusions would imply that the transfer of mean values is probably relatively good for ITNs and within Nigeria and countries similar to Nigeria. It is also likely that transferring the value function from a meta-regression is more reliable for transferring across dissimilar contexts, and this has been one of the driving forces behind such work elsewhere (Rosenberger and Loomis, 2000; Shrestha, 2001; Engel, 2002; Johnston et al., 2005; Johnston et al., forthcoming, in Moeltner et al., 2006). Policy contexts facing different 
risks of malaria might therefore be better use the general value function provided here to transfer data and this itself should be a subject of further research.

It was surprisingly difficult to compare average WTP across studies. One of the main issues highlighted by this review is the inadequate reporting of WTP studies; data from only 24/59 articles could be included as many did not even report mean WTP values. Difficulties were compounded because those providing mean WTP values reported insufficient data to facilitate comparison. The most surprising issue was the exclusion of, and lack of clarity about, zero values. It is also curious that when studies chose not to report zero values, not only was the percentage of zero values not given but no distinction was made between zeros and missing values, let alone type of 'missingness' (e.g. survey or question nonresponse). This would suggest that such studies could be the focus of multiple forms of untested bias, raising serious questions about the quality of some data.

There was an astonishing lack of basic data that was important for interpretation, not only across but also within studies. The missing information included characteristics of the sample (e.g. who the respondent was, age, income, gender), disease (e.g. exposure to malaria), study design (e.g. method of eliciting WTP, level of starting bids, whether 'don't know' responses had been elicited and, if so, their extent and how they were treated) and methods of analysis (e.g. methods of calculating mean WTP, methods of dealing with 'don't know' and other missing data). Problems of lack of data could potentially be overcome in the future by contacting authors, although we are aware that there is rarely a high response rate (Pai et al., 2003; Wong and Wong, 2007). If we had had more data, we could have potentially accounted for price and other economic variables, studied and controlled for a greater range of design effects and been more aware of the true quality of data.

\section{CONCLUSIONS}

This study is the first example of the use of meta-analysis and meta-regression to determine WTP values in health economics. Mean estimates of WTP for three broad categories of malaria control goods/services (ITNs, other preventive services and treatment) are provided along with evidence of how to transfer these values across countries, controlling for a limited number of sample and design effects. The main concern with the evidence to date is the need to account for a broader range of economic explanators that are study specific (in a comparable way) and the ability to transfer results into malaria contexts beyond those represented by the data. Future studies need to improve the reporting of the WTP variable and its construction as well as providing information on a range of key explanatory variables.

\section{APPENDIX A: DEFINITION OF ELICITATION METHOD FOR WTP}

Bidding game (BG)

Respondents are faced with several rounds of discrete choice (yes, no) questions, followed by a final open-ended WTP question (Bateman et al., 2002). It is modelled on the real-life situation in which individuals are asked to state a price (Mitchel and Carson, 1993). Its most important characteristic is the simple nature of the choice it required the respondent to make (Mitchel and Carson, 1993). The bidding process will capture the highest price consumers are willing to pay, thereby measuring the full consumer surplus and the likelihood that the process of iteration will enable the respondent to more fully consider the value of amenity (Mitchel and Carson, 1993). With this elicitation method, the actual WTP amount from the respondent about his or her preferences is obtained.

Single-bound dichotomous choice (SBDC)
SBDC uses a large number of predetermined prices, chosen to incorporate expected maximum WTP amounts of most respondents for the amenity. Respondents only have to make a judgement about a given price, in the same 
Single-bound dichotomous choice with open-ended question $(\mathrm{SBDC}+\mathrm{OE})$

Structured haggling $(\mathrm{SH})$

Open-ended question (OE)

Payment card (PC) way they decide whether or not to buy a supermarket good at a certain price. It is argued that it is providing incentives for the truthful revelation of preferences under certain circumstances, values spread randomly across a sample to allow structure of demand across the sample as a whole, thus, as it is in the respondent's strategic interest to accept the bid if his or her WTP is greater or equal than the price asked and to reject otherwise (Bateman et al., 2002). $\mathrm{SBDC}+\mathrm{OE}$ is an offer of one dichotomous choice question and a second open-ended question. Source: Mitchel and Carson (1993)

The SH method resembles the $\mathrm{BG}$ and $\mathrm{SBDC}+\mathrm{OE}$, but allows more steps the $\mathrm{BG}$ and $\mathrm{SBDC}+\mathrm{OE}$ to mimic the haggling process if needed, so that respondents that are willing to pay are coaxed to state the highest possible amount they can pay. Source: Mitchel and Carson (1993)

The direct open-ended elicitation format is a straightforward way of uncovering values, asking the respondent what maximum price he/she is willing to pay for the described good in one question (Bateman et al., 2002).

This method seeks to maintain the properties of the direct question approach (i.e. BG) while increasing the response rates for the WTP questions by providing respondents with a visual aid which contains a large array of potential WTP amounts, ranging from $\$ 0$ to some large amount in response to the questions what is your maximum WTP for X. Source: Mitchel and Carson (1993).

APPENDIX B: CHARACTERISTICS OF ARTICLES INCLUDED IN THE DESCRIPTIVE ANALYSIS

\begin{tabular}{|c|c|c|c|c|c|}
\hline Type of good ${ }^{a}$ & $\begin{array}{c}\text { Elicitation } \\
\text { format }\end{array}$ & Country & $\begin{array}{l}\text { Regression } \\
\text { model }\end{array}$ & $\begin{array}{l}\text { Dependent } \\
\text { variable }\end{array}$ & References \\
\hline \multicolumn{6}{|l|}{ ITNs } \\
\hline An ITN & Not specified & Gambia & No regression & & MacCormack et al. (1989) \\
\hline ITNs & BG & India & No regression & & Bhatia (2005) \\
\hline ITNs & BG & India & No regression & & $\begin{array}{l}\text { Bhatia and Fox-Rushby } \\
\text { (2002) }\end{array}$ \\
\hline ITNs & $\mathrm{BG}$ & Mozambique & Logistic & WTP for ITNs & Dgedge (2000) \\
\hline ITNs & $\mathrm{OE}, \mathrm{SBDC}$ & Kenya & No regression & & Guyatt et al. (2002) \\
\hline ITNs & $\mathrm{SBDC}+\mathrm{OE}^{\mathrm{b}}$ & Tanzania & No regression & & Mujinja et al. (2004) \\
\hline ITNs & $\mathrm{BG}, \mathrm{SBDC}+\mathrm{OE}, \mathrm{SH}$ & Nigeria & No regression & & Onwujekwe (2004) \\
\hline ITNs & $\mathrm{BG}, \mathrm{SBDC}+\mathrm{OE}$ & Nigeria & OLS & $\begin{array}{l}\text { Variation in WTP } \\
\text { for ITNs (in general) }\end{array}$ & Onwujekwe (2001) \\
\hline ITNs & $\mathrm{SBDC}+\mathrm{OE}, \mathrm{OE}$ & Nigeria & $\begin{array}{l}\text { Logistic and } \\
\text { Heckman model }\end{array}$ & $\begin{array}{l}\text { Altruistic WTP } \\
\text { (in both models) }\end{array}$ & $\begin{array}{l}\text { Onwujekwe and } \\
\text { Uzochukwu (2004) }\end{array}$ \\
\hline ITNs & $\mathrm{BG}$ plus $\mathrm{SBDC}+\mathrm{OE}$ plus $\mathrm{SH}$ & Nigeria & OLS & WTP for ITN & Onwujekwe et al. (2004b) \\
\hline ITNs & $\mathrm{BG}, \mathrm{SBDC}+\mathrm{OE}, \mathrm{SH}$ & Nigeria & No regression & & Onwujekwe et al. (2005a) \\
\hline ITNs & $\mathrm{OE}$ & Nigeria & Tobit & $\begin{array}{l}\text { Altruistic WTP for } \\
\text { ITN (for nets for } \\
\text { other people } \\
\text { combined for } \\
\text { four different areas) }\end{array}$ & Onwujekwe et al. (2002) \\
\hline ITNs & $\mathrm{BG}$ plus $\mathrm{SBDC}+\mathrm{OE}^{\mathrm{c}}$ & Nigeria & OLS & $\begin{array}{l}\text { WTP for personal } \\
\text { and for other's ITNs }\end{array}$ & Onwujekwe et al. (2001) \\
\hline
\end{tabular}


META-ANALYSIS OF WTP FOR MALARIA CONTROL

Appendix B. Continued.

\begin{tabular}{|c|c|c|c|c|c|}
\hline Type of good ${ }^{\mathrm{a}}$ & $\begin{array}{l}\text { Elicitation } \\
\text { format }\end{array}$ & Country & $\begin{array}{l}\text { Regression } \\
\text { model }\end{array}$ & $\begin{array}{l}\text { Dependent } \\
\text { variable }\end{array}$ & References \\
\hline ITNs & $\mathrm{SBDC}+\mathrm{OE}$ & Mozambique & $\begin{array}{l}\text { Multiple } \\
\text { regression analysis }\end{array}$ & WTP for bed nets & Chase et al. (2009) \\
\hline ITNs & BG & Uganda & Tobit & $\begin{array}{l}\text { Respondent's } \\
\text { average buying or } \\
\text { selling bid for up to } \\
\text { three nets }\end{array}$ & Hoffmann (2009) \\
\hline ITNs & Not specified & Ethiopia & No regression & & Jima et al. (2005) \\
\hline ITNs & Not specified & Burma & No regression & & Lin et al. (2000) \\
\hline ITNs & $\mathrm{SBDC}+\mathrm{OE}$ & Tanzania & $\begin{array}{l}\text { Least squares } \\
\text { random effects } \\
\text { model and logit }\end{array}$ & WTP for an ITN & Mujinja (2006) \\
\hline Long-lasting ITNs & Not specified & India & No regression & & Gunasekaran et al. (2009) \\
\hline Long-lasting ITNs & $\mathrm{BG}$ & Ethiopia & Logit & WTP for an ITN & Legesse et al. (2007) \\
\hline $\begin{array}{l}\text { ITNs (protection for } \\
3 \text { or } 4 \text { years) and } \\
\text { malaria vaccine } \\
\text { (preventing } \\
\text { contracting malaria } \\
\text { for one year) }\end{array}$ & SBDC & Ethiopia & $\begin{array}{l}\text { Truncated } \\
\text { Poisson }\end{array}$ & $\begin{array}{l}\text { WTP for all } \\
\text { vaccines } \\
\text { for next year and } \\
\text { WTP for ITNs }\end{array}$ & Cropper et al. (2000) \\
\hline $\begin{array}{l}\text { ITNs and ITNs } \\
\text { retreatment } \\
\text { (permethrin) }\end{array}$ & $\begin{array}{l}\text { OE/dichotomous choice } \\
\text { with open-ended question }\end{array}$ & Kenya & No regression & & Alaii et al. (2003) \\
\hline $\begin{array}{l}\text { ITNs and ITNs } \\
\text { retreatment once a } \\
\text { year }\end{array}$ & BG & Nigeria & Tobit & $\begin{array}{l}\text { WTP for small and } \\
\text { large nets and } \\
\text { WTP for } \\
\text { retreatment }\end{array}$ & $\begin{array}{l}\text { Onwujekwe and Nwagbo } \\
\text { (2002) }\end{array}$ \\
\hline $\begin{array}{l}\text { ITNs and retreatment } \\
\text { of ITNs }\end{array}$ & $\mathrm{BG}, \mathrm{SBDC}+\mathrm{OE}, \mathrm{SH}$ & Nigeria & OLS & $\begin{array}{l}\text { WTP for } \\
\text { retreatment }\end{array}$ & Onwujekwe et al. (2004a) \\
\hline $\begin{array}{l}\text { ITNs and retreatment } \\
\text { of ITNs }\end{array}$ & $\mathrm{BG}, \mathrm{SBDC}+\mathrm{OE}, \mathrm{SH}$ & Nigeria & No regression & & Onwujekwe et al. (2005c) \\
\hline $\begin{array}{l}\text { ITNs and malaria } \\
\text { cure }\end{array}$ & Not specified & Sierra Leone & OLS & $\begin{array}{l}\text { WTP for ITNs and } \\
\text { malaria cure }\end{array}$ & Juana et al. (2004) \\
\hline $\begin{array}{l}\text { ITNs and vaccine } \\
\text { (preventing malaria } \\
\text { for one year) }\end{array}$ & $\begin{array}{l}\text { Units per stated price } \\
\text { (SBDC) }\end{array}$ & Ethiopia & $\begin{array}{l}\text { Truncated } \\
\text { Poisson }\end{array}$ & $\begin{array}{l}\text { WTP for ITNs and } \\
\text { vaccines }\end{array}$ & Lampietti et al. (1999) \\
\hline $\begin{array}{l}\text { ITNs, annual IRHS, } \\
\text { LWC and SS }\end{array}$ & BG & Sudan & Tobit & $\begin{array}{l}\text { WTP for ITNs, } \\
\text { IRHS, LWC and SS }\end{array}$ & Onwujekwe et al. (2005b) \\
\hline \multicolumn{6}{|l|}{ Other prevention } \\
\hline $\begin{array}{l}\text { Bed net }{ }^{\mathrm{e}} \text { and } \\
\text { hypothetical vaccine }\end{array}$ & Not specified & Ethiopia & Probit & $\begin{array}{l}\text { Differences between } \\
\text { husbands and wives } \\
\text { with respect to the } \\
\text { decision to purchase } \\
\text { preventive health } \\
\text { care }\end{array}$ & Lampietti (1999) \\
\hline $\begin{array}{l}\text { Community-based } \\
\text { malaria control } \\
\text { scheme }\end{array}$ & $\mathrm{SBDC}+\mathrm{OE}$ & Cameroon & $\begin{array}{l}\text { OLS, Heckman } \\
\text { two-stage model, } \\
\text { FIML }^{\mathrm{f}}\end{array}$ & $\begin{array}{l}\text { WTP for the } \\
\text { community-based } \\
\text { malaria control } \\
\text { scheme }\end{array}$ & Fonta et al. (2010) \\
\hline $\begin{array}{l}\text { Indoor spraying } \\
\text { within a year }\end{array}$ & Not specified & Indonesia & No regression & & Sanjana et al. (2006) \\
\hline $\begin{array}{l}\text { Insecticide for bed } \\
\text { net impregnation }\end{array}$ & Not specified & Gambia & No regression & & Mills et al. (1994) \\
\hline $\begin{array}{l}\text { Malaria control } \\
\text { within a } \\
\text { community-led } \\
\text { financing } \\
\text { framework }\end{array}$ & Payment card & Cameroon & $\begin{array}{l}\text { Heckman two- } \\
\text { stage model and } \\
\text { OLS }\end{array}$ & $\begin{array}{l}\text { WTP for malaria } \\
\text { control }\end{array}$ & Munpuibevi et al. (2010) \\
\hline
\end{tabular}




\section{TRAPERO-BERTRAN ET AL.}

Appendix B. Continued.

\begin{tabular}{|c|c|c|c|c|c|}
\hline Type of good ${ }^{a}$ & $\begin{array}{l}\text { Elicitation } \\
\text { format }\end{array}$ & Country & $\begin{array}{l}\text { Regression } \\
\text { model }\end{array}$ & $\begin{array}{l}\text { Dependent } \\
\text { variable }\end{array}$ & References \\
\hline $\begin{array}{l}\text { Malaria control and } \\
\text { eradication }\end{array}$ & BG & Ghana & Probit & $\begin{array}{l}\text { WTP for malaria } \\
\text { control/eradication }\end{array}$ & $\begin{array}{l}\text { Ankomah-Asante } \text { et al. } \\
(2005)\end{array}$ \\
\hline $\begin{array}{l}\text { Malaria rapid } \\
\text { diagnostic test }\end{array}$ & BG & Nigeria & No regression & & Uzochukwu et al. (2010) \\
\hline $\begin{array}{l}\text { Malaria test kit for } \\
\text { children } 5 \text { years and } \\
\text { younger }\end{array}$ & BG & Tanzania & OLS & $\begin{array}{l}\text { WTP for malaria } \\
\text { diagnostics }\end{array}$ & Rennie et al. (2009) \\
\hline $\begin{array}{l}\text { Mosquito control } \\
\text { (chemical and } \\
\text { nonchemical tools) }\end{array}$ & Payment card & US & No regression & & Ofiara et al. (1986) \\
\hline $\begin{array}{l}\text { Net treatment with } \\
\text { insecticide }\end{array}$ & Not specified & Burkina Faso & No regression & & Okrah et al. (2002) \\
\hline PfPv test kit & $\mathrm{BG}$ & Burma & OLS & WTP for test kit & Cho-Min-Naing et al. (2000) \\
\hline $\begin{array}{l}\text { Prevention treatment } \\
\text { (malaria control) }^{\mathrm{g}}\end{array}$ & Dichotomous choice & Ghana & Probit & $\begin{array}{l}\text { Qualitative choice } \\
\text { of amount an } \\
\text { individual is } \\
\text { willing to pay }\end{array}$ & $\begin{array}{l}\text { Ankomah-Asante and } \\
\text { Asenso-Okyere (2003) }\end{array}$ \\
\hline $\begin{array}{l}\text { Preventive care } \\
\text { (mosquito nets) }^{\mathrm{h}, \mathrm{i}}\end{array}$ & Not specified & Sri Lanka & Not specified & $\begin{array}{l}\text { WTP for curative } \\
\text { care and WTP for } \\
\text { ITNs }\end{array}$ & Attanayake (Undated) \\
\hline $\begin{array}{l}\text { Retreatment for } \\
\text { mosquito nets once a } \\
\text { year }\end{array}$ & BG & Nigeria & OLS & WTP for retreatment & Onwujekwe et al. (2000) \\
\hline Vaccine & $\begin{array}{l}\text { Units per stated price } \\
\text { (SBDC) }\end{array}$ & India & $\begin{array}{l}\text { Probit and } \\
\text { binomial } \\
\text { regression }\end{array}$ & $\begin{array}{l}\text { WTP for sum of } \\
\text { count of vaccines }\end{array}$ & Prabhu (2010) \\
\hline $\begin{array}{l}\text { Vaccine (for } 3,6 \text { and } \\
12 \text { years of } \\
\text { protection) }\end{array}$ & Payment card & Nigeria & $\begin{array}{l}\text { Multiple regression } \\
\text { analysis }\end{array}$ & $\begin{array}{l}\text { WTP for malaria } \\
\text { vaccine }\end{array}$ & Udezi et al. (2010) \\
\hline $\begin{array}{l}\text { Vaccine (prevention } \\
\text { from malaria for one } \\
\text { year) }\end{array}$ & $\mathrm{SBDC}^{\mathrm{j}}$ & Tanzania & Probit & $\begin{array}{l}\text { Probability of } \\
\text { purchasing } \\
\text { vaccines for the } \\
\text { household }\end{array}$ & Poulos (2000) \\
\hline $\begin{array}{l}\text { Vaccine (preventing } \\
\text { malaria for one year) }\end{array}$ & SBDC & Mozambique & Probit & $\begin{array}{l}\text { Probability that a } \\
\text { respondent will } \\
\text { choose to pay for } \\
\text { the hypothetical } \\
\text { malaria vaccine }\end{array}$ & Whittington et al. (2003) \\
\hline $\begin{array}{l}\text { Vaccine (preventing } \\
\text { malaria of } n \\
\text { household members } \\
\text { for } 1 \text { year) }\end{array}$ & $\begin{array}{l}\text { Units per stated price } \\
\text { (SBDC) }\end{array}$ & Ethiopia & Truncated Poisson & Demand for vaccines & Cropper et al. (2004) \\
\hline $\begin{array}{l}\text { Vaccine to protect } \\
\text { women against } \\
\text { maternal malaria } \\
\text { and vaccine to } \\
\text { protect } \\
\text { children against } \\
\text { severe disease }\end{array}$ & Dichotomous choice & Burkina Faso & OLS & $\begin{array}{l}\text { WTP for maternal } \\
\text { and childhood } \\
\text { malaria vaccine }\end{array}$ & Sauerborn et al. (2005) \\
\hline \multicolumn{6}{|l|}{ Treatment } \\
\hline Drugs & SBDC & $\begin{array}{l}\text { Central } \\
\text { African } \\
\text { Republic }\end{array}$ & Logistic regression & $\begin{array}{l}\text { WTP for drugs to } \\
\text { treat malaria }\end{array}$ & Weaver et al. (1993) \\
\hline Drugs & SBDC & $\begin{array}{l}\text { Central } \\
\text { African } \\
\text { Republic }\end{array}$ & No regression & & Weaver et al. (1996) \\
\hline
\end{tabular}


META-ANALYSIS OF WTP FOR MALARIA CONTROL

Appendix B. Continued.

\begin{tabular}{|c|c|c|c|c|c|}
\hline Type of good ${ }^{\mathrm{a}}$ & $\begin{array}{l}\text { Elicitation } \\
\text { format }\end{array}$ & Country & $\begin{array}{l}\text { Regression } \\
\text { model }\end{array}$ & $\begin{array}{l}\text { Dependent } \\
\text { variable }\end{array}$ & References \\
\hline $\begin{array}{l}\text { Drugs: chloroquine } \\
\text { (several days) and } \\
\text { sulfadoxine- } \\
\text { pyrimethamine } \\
\text { (1 day) }\end{array}$ & BG & Nigeria & OLS & WTP for treatment & Onwujekwe et al. (2007) \\
\hline $\begin{array}{l}\text { Drugs: } \\
\text { combination } \\
\text { therapy } \\
\text { (artemisinin based) } \\
\text { for uncomplicated } \\
\text { malaria }\end{array}$ & SBDC & Tanzania & Logit & $\begin{array}{l}\text { WTP for the } \\
\text { combination } \\
\text { therapy } \leq \text { Tanzanian } \\
\text { Shillings (TSh) } 500 \\
\text { respective } \\
\text { WTP }>\text { TSh } 500\end{array}$ & Saulo et al. (2008) \\
\hline $\begin{array}{l}\text { Drugs: } \\
\text { combination } \\
\text { therapy } \\
\text { (chroloquine and } \\
\text { sulfadoxine- } \\
\text { pyrimethamine) }\end{array}$ & $\mathrm{BG}, \mathrm{SH}$ & Nigeria & Logistic and OLS & $\begin{array}{l}\text { WTP for } \\
\text { combination therapy }\end{array}$ & Onwujekwe et al. (2004c) \\
\hline $\begin{array}{l}\text { Drugs: } \\
\text { monotheraphy } \\
\text { (unit-dose } \\
\text { prepacked } \\
\text { chloroquine) }\end{array}$ & Not specified & Uganda & No regression & & Kilian et al. (2003) \\
\hline $\begin{array}{l}\text { Drugs: three } \\
\text { combination therapy } \\
\text { and monotherapy }{ }^{\mathrm{k}}\end{array}$ & BG & Tanzania & No regression & & Wiseman et al. (2005) \\
\hline $\begin{array}{l}\text { Improved quality of } \\
\text { malaria treatment }\end{array}$ & BG & Nigeria & OLS & $\begin{array}{l}\text { WTO for } \\
\text { improved quality } \\
\text { of malaria } \\
\text { treatment }\end{array}$ & Onwujekwe et al. (2006) \\
\hline Improved treatment $^{\mathrm{m}}$ & Payment card & Zambia & $\begin{array}{l}\text { Interval } \\
\text { regression }\end{array}$ & $\begin{array}{l}\text { WTP for malaria } \\
\text { improved treatment }\end{array}$ & $\begin{array}{l}\text { Masiye and Rehnberg } \\
(2005)\end{array}$ \\
\hline $\begin{array}{l}\text { Malaria insurance } \\
\text { scheme (monthly } \\
\text { payment) }\end{array}$ & Dichotomous choice & Ghana & Probit & $\begin{array}{l}\text { WTP for malaria } \\
\text { insurance }\end{array}$ & $\begin{array}{l}\text { Asafu-Adjaye and Dzator } \\
\text { (2003) }\end{array}$ \\
\hline $\begin{array}{l}\text { Combination of } \\
\text { malaria treatment, } \\
\text { bed nets, space } \\
\text { spraying and } \\
\text { eradication of } \\
\text { malaria }\end{array}$ & $\mathrm{SBDC}+\mathrm{OE}$ & Nigeria & OLS & $\begin{array}{l}\text { WTP for malaria } \\
\text { eradication and } \\
\text { control }\end{array}$ & Jimoh et al. (2007) \\
\hline
\end{tabular}

${ }^{\mathrm{a}}$ All treatment interventions were for single treatment.

${ }^{\mathrm{b}}$ Although it is not clearly stated in the article, according to the description of the methods, this article was classified as using SBDC + OE.

${ }^{\text {c } T h e ~ b i n a r y ~ w i t h ~ f o l l o w-u p ~ m e t h o d ~ i s ~ o n l y ~ u s e d ~ i n ~ t h i s ~ s t u d y ~ t o ~ c a l c u l a t e ~ t h e ~ m e a n ~ W T P ~ f o r ~ o n e ~ N i g e r i a ' s ~ a r e a ~(c a l l e d ~ O r b a) . ~}$

${ }^{\mathrm{d}}$ IRHS, indoor residual house spraying; LWC, larviciding with chemicals; SS, fogging or space spraying.

${ }^{\mathrm{e}}$ This bed net was not specified as being impregnated; hence, it is treated differently than ITNs.

${ }^{\mathrm{f}}$ Full information maximum likelihood.

${ }^{\mathrm{g}}$ This study determines WTP for malaria treatment and prevention at the same time. It has been classified as a prevention article because the treatment was not well specified.

${ }^{\mathrm{h}}$ This net is not specified as being impregnated and therefore is treated differently than ITNs.

${ }^{\mathrm{i}}$ Although this study indicated that WTP is calculated for both curative and preventive care for malaria control, only WTP estimates for preventive care are reported.

${ }^{\mathrm{j}}$ This article has been classified as SBDC, although there is a follow-up question at the end to obtain the maximum WTP value.

${ }^{\mathrm{k}}$ This includes arthemeter-lumefantrine, amodiaquine + sulfadoxine-pyrimethamine and amodiaquine + artesunate. The monotherapy is based in amodiaquine.

${ }^{1}$ The interventions presented were treatments in general hospitals, by community health workers, in primary healthcare centers, from trained patent medicine dealers and in private clinics and hospitals

${ }^{\mathrm{m}}$ Improved malaria treatment is based on access to a qualified doctor; nursing care; laboratory and other diagnostic services; access to all necessary anti-malarial medicines; hospitalization costs, such as food, laundry, etc., as deemed necessary by clinicians; and health facility managers. 


\section{APPENDIX C: SUMMARY RESULTS, BY VARIABLE TESTED, FROM REGRESSIONS OF MEAN WTP FOR GOODS AND SERVICES FOR MALARIA CONTROL}

\begin{tabular}{|c|c|c|c|c|c|c|c|}
\hline Variable & $\begin{array}{l}\text { No. } \\
\text { articles }\end{array}$ & $\begin{array}{l}\text { No. total } \\
\text { coefficients }\end{array}$ & $\begin{array}{l}\text { No. } \\
\text { significant } \\
\text { coefficients }\end{array}$ & $\begin{array}{c}\text { Total } \\
\text { positive } \\
\text { coefficients }\end{array}$ & $\begin{array}{l}\text { Significance level } \\
\text { positive coefficients } \\
\text { by publication } \\
\text { number }\end{array}$ & $\begin{array}{c}\text { Total } \\
\text { negative } \\
\text { coefficients }\end{array}$ & $\begin{array}{c}\text { Significance level } \\
\text { negative coefficients } \\
\text { by publication } \\
\text { number }\end{array}$ \\
\hline Gender & 20 & 33 & 17 & 26 & $\begin{array}{l}\text { 66.1, 66.2, 89, 76.1***, } \\
76.4^{*}, 3.1,8.1^{* * *}, 8.2, \\
9.1^{* *}, 9.2,10^{* *}, \\
12.1^{* * *}, 12.2^{* * *}, 4^{* *}, \\
76.2^{* *}, 90.2,57.2 \\
90.1,90.2^{* *}, 21.1^{* *}, \\
21.2^{* *}, 105^{*}, 119.1^{*}, \\
131.1,131.2,131.3\end{array}$ & 7 & $\begin{array}{l}57.1 * *, 23.3 * * * \\
3.2,3.3,23.1 * * * \\
23.2,75.1\end{array}$ \\
\hline Marital status & 19 & 29 & 7 & 13 & $\begin{array}{l}89,57.1 * *, 23.3,76.4 \\
23.1,76.2,12.1,12.2 \\
57.2,90.1,111^{* * *} \\
131.1,131.3\end{array}$ & 16 & $\begin{array}{l}3.1,3.2 * *, 3.3,8.1, \\
8.2,66.1,66.29 .1, \\
9.2,10^{* * *}, 4^{* *}, \\
23.2, \\
90.2^{*} 21.1^{*}, 123, \\
131.2\end{array}$ \\
\hline Education & 17 & 30 & 15 & 23 & $\begin{array}{l}\text { 66.1***, 66.2, 23.3***, } \\
76.3^{*}, 3.3^{*}, 8.1,8.2, \\
23.1^{* * *}, 23.2,(64.1 \times \\
2)^{* * *},(64.2 \times 2)^{* * *}, \\
10^{* * *}, 90.1,90.2^{* * *}, \\
60,21.1^{* *}, 111^{* * *}, \\
123,131.1,131.2, \\
131.3\end{array}$ & 7 & $\begin{array}{l}9.1,9.2,12.1 \\
12.2^{* *}, 21.2^{* * *}, \\
21.2,89\end{array}$ \\
\hline Age & 16 & 28 & 11 & 4 & $66.1,10,21.1,131.1$ & 24 & $\begin{array}{l}59,66.2 * * *, 57.1 * *, \\
8.1,8.2,23.3^{* * *}, \\
76.1^{* *}, 76.4,9.1, \\
9.2,12.1^{* * *}, 12.2, \\
23.1 * * *, 23.2,76, \\
90.2,57.2,21.1^{* * *}, \\
21.2^{* * *}, 21.2^{* *}, \\
119.1 * *, 119.2^{*}, \\
131.2,131.3\end{array}$ \\
\hline Household size & 13 & 27 & 13 & 23 & $\begin{array}{l}(59 \times 8), 3.3,4^{*}, \\
9.1^{* *}, 9.2,10^{* *}, 12.1^{*}, \\
12.2,75,21.1^{*}, 21.2 \\
119.1^{* *}, 126.1^{* * *}, \\
126.2^{* * *}, 126.3^{* * *}, \\
111^{* * *}\end{array}$ & 4 & $\begin{array}{l}8.1^{* * *}, 8.2^{* * *} \\
119.2 * *, 123\end{array}$ \\
\hline $\begin{array}{l}\text { Status in } \\
\text { household }\end{array}$ & 10 & 17 & 7 & 10 & $\begin{array}{l}23.3,76.3,76.4^{*}, \\
3.2^{* *}, 3.3^{*}, 10^{* *}, \\
23.1,23.2,76,90.2\end{array}$ & 7 & $\begin{array}{l}3.1,9.1,9.2,21.1^{* *}, \\
21.2^{*}, 21.1^{* * *}, \\
119.1\end{array}$ \\
\hline $\begin{array}{l}\text { Actual incidence } \\
\text { of malaria }\end{array}$ & 10 & 16 & 7 & 6 & $\begin{array}{l}3.1,10^{* * *}, 21.1 * * \\
3.1 * *, 131.1,131.2\end{array}$ & 10 & $\begin{array}{l}3.2 * *, 9.1 *, 9.2, \\
12.1,12.2^{* *}, 90.1, \\
119.1,3.2 *, 10, \\
131.3\end{array}$ \\
\hline Occupation & 7 & 14 & 4 & 7 & $\begin{array}{l}23.3 * * *, 23.1 * * *, 23.2 \\
10,123,131.1,131.2\end{array}$ & 7 & $\begin{array}{l}66.1 * * *, 66.2 * * * \\
89,10 \times 3,131.3\end{array}$ \\
\hline $\begin{array}{l}\text { Socioeconomic } \\
\text { status }\end{array}$ & 6 & 20 & 18 & 20 & $\begin{array}{l}76.1^{* * *}, 76.3^{* * *}, \\
76.4^{* * *}, 64.1^{* * * *}, \\
64.1^{*}, 64.2^{* * *}, 64.2, \\
76.2^{* * * *}, 10^{* * * *}, \\
21.2 .1^{* * *}, 21.2 .2, \\
21.2 .3^{*},(21.1 \times 3)^{* * *}, \\
(21.2 \times 2)^{* *}, 21.2^{*}, \\
119.1^{* * *}, 119.2^{* * * *}\end{array}$ & 0 & \\
\hline
\end{tabular}


META-ANALYSIS OF WTP FOR MALARIA CONTROL

Appendix C. Continued.

\begin{tabular}{|c|c|c|c|c|c|c|c|}
\hline Variable & $\begin{array}{l}\text { No. } \\
\text { articles }\end{array}$ & $\begin{array}{l}\text { No. total } \\
\text { coefficients }\end{array}$ & $\begin{array}{l}\text { No. } \\
\text { significant } \\
\text { coefficients }\end{array}$ & $\begin{array}{c}\text { Total } \\
\text { positive } \\
\text { coefficients }\end{array}$ & $\begin{array}{c}\text { Significance level } \\
\text { positive coefficients } \\
\text { by publication } \\
\text { number }^{\mathrm{a}}\end{array}$ & $\begin{array}{c}\text { Total } \\
\text { negative } \\
\text { coefficients }\end{array}$ & $\begin{array}{c}\text { Significance level } \\
\text { negative coefficients } \\
\text { by publication } \\
\text { number }\end{array}$ \\
\hline $\begin{array}{l}\text { Household } \\
\text { income }\end{array}$ & 6 & 7 & 6 & 7 & $\begin{array}{l}89 * * *, 59 * * *, \\
57.1 * *, 57.2, \\
111 * * *, 66.1 * * *, \\
66.2 * * *\end{array}$ & 0 & \\
\hline $\begin{array}{l}\text { Expenditure to } \\
\text { treat malaria }\end{array}$ & 6 & 10 & 3 & 8 & $\begin{array}{l}3.2,3.3^{*}, 13,9.1, \\
9.2,12.1,4^{* * *}, \\
111^{* * *}\end{array}$ & 2 & $3.1,12.2 *$ \\
\hline $\begin{array}{l}\text { Distance to nearest } \\
\text { health facility }\end{array}$ & 5 & 8 & 6 & 2 & $1.2 * *, 60$ & 6 & $\begin{array}{l}8.1 * * *, 8.2 * *, \\
126.1 * * *, 126.2 * * *, \\
126.3 * * *, 89\end{array}$ \\
\hline $\begin{array}{l}\text { Household } \\
\text { wealth }\end{array}$ & 4 & 8 & 5 & 7 & $\begin{array}{l}105^{* *}, 123, \\
126.1^{* * *}, 126.2^{* * *}, \\
126.3^{* * *}, 131.1^{* *}, \\
131.2\end{array}$ & 1 & 131.3 \\
\hline Household savings & 4 & 5 & 5 & 5 & $\begin{array}{l}13 * *, 9.1 * * *, 9.2 * * \\
4 * * *, 111^{* * *}\end{array}$ & 0 & \\
\hline Price & 4 & 4 & 4 & 0 & & 4 & $\begin{array}{l}59 * * *, 91 *, 57.1 * *, \\
57.2 * *\end{array}$ \\
\hline $\begin{array}{l}\text { No. children in } \\
\text { household }\end{array}$ & 4 & 5 & 3 & 2 & $66.2 * * *, 57.2$ & 3 & $59 * *, 66.1,57.1 * *$ \\
\hline $\begin{array}{l}\text { Household cost of } \\
\text { illness }\end{array}$ & 4 & 6 & 1 & 4 & $\begin{array}{l}57.1^{* *}, 131.1 \\
131.2,131.3\end{array}$ & 2 & $57.2,59$ \\
\hline $\begin{array}{l}\text { Average annual } \\
\text { expenditure (food, } \\
\text { celebrations, } \\
\text { clothing, gifts, } \\
\text { school fees) }\end{array}$ & 3 & 8 & 3 & 7 & $\begin{array}{l}13^{*}, 13,9.1,9.1^{* * *}, \\
9.2 \times 2,12.1\end{array}$ & 1 & $12.2 * * *$ \\
\hline Value of first bid & 2 & 3 & 2 & 2 & $8.1 * * *, 8.2 * * *$ & 1 & 23.3 \\
\hline Altitude & 2 & 2 & 1 & 1 & 57.2 & 1 & $57.1 * *$ \\
\hline $\begin{array}{l}\text { WTP for own } \\
\text { ITNs }\end{array}$ & 2 & 5 & 5 & 5 & $\begin{array}{l}90.1 * * *, 90.2 * * *, \\
90.1 * * *, 90.2 * * *, \\
4 * * *\end{array}$ & 0 & \\
\hline Missing wage & 2 & 2 & 0 & 2 & $57.1,57.2$ & 0 & \\
\hline $\begin{array}{l}\text { Ownership of } \\
\text { electrical } \\
\text { appliances (radio, } \\
\text { grinding machine) }\end{array}$ & 2 & 6 & 3 & 6 & $\begin{array}{l}3.1^{*}, 3.2,3.3^{*}, 3.3 \\
90.1^{*}, 90.2\end{array}$ & 0 & \\
\hline $\begin{array}{l}\text { Ownership of } \\
\text { method of transport } \\
\text { (motorcycle, } \\
\text { bicycle, motorcar) }\end{array}$ & 2 & 7 & 2 & 3 & $90.1,90.2^{*}, 90.2$ & 4 & $\begin{array}{l}3.1,90.1 * * *, 90.2 \\
90.1\end{array}$ \\
\hline $\begin{array}{l}\text { Previous } \\
\text { purchase of nets }\end{array}$ & 2 & 2 & 0 & 2 & $3.2,90.1$ & 0 & \\
\hline $\begin{array}{l}\text { Reads newspaper } \\
\text { easily (literacy) }\end{array}$ & 2 & 2 & 1 & 1 & $57.1 * *$ & 1 & 57.2 \\
\hline $\begin{array}{l}\text { Resident of } \\
\text { urban area }\end{array}$ & 2 & 8 & 4 & 1 & 60 & 7 & $\begin{array}{l}8.1,8.2,(60 \times 2)^{* *}, \\
(60 \times 2)^{* * *}, 60\end{array}$ \\
\hline $\begin{array}{l}\text { Health status of } \\
\text { the respondents }\end{array}$ & 2 & 4 & 2 & 3 & $(75 \times 2)^{* *}, 75$ & 1 & 60 \\
\hline Food cost & 1 & 3 & 2 & 3 & $90.1 * *, 90.1 * *, 90.2$ & 0 & \\
\hline $\begin{array}{l}\text { Had other } \\
\text { illnesses }\end{array}$ & 1 & 2 & 1 & 2 & $90.1 * *, 90.2$ & 0 & \\
\hline
\end{tabular}




\section{TRAPERO-BERTRAN ET AL.}

Appendix C. Continued.

\begin{tabular}{|c|c|c|c|c|c|c|c|}
\hline Variable & $\begin{array}{l}\text { No. } \\
\text { articles }\end{array}$ & $\begin{array}{l}\text { No. total } \\
\text { coefficients }\end{array}$ & $\begin{array}{l}\text { No. } \\
\text { significant } \\
\text { coefficients }\end{array}$ & $\begin{array}{c}\text { Total } \\
\text { positive } \\
\text { coefficients }\end{array}$ & $\begin{array}{c}\text { Significance level } \\
\text { positive coefficients } \\
\text { by publication } \\
\text { number }\end{array}$ & $\begin{array}{c}\text { Total } \\
\text { negative } \\
\text { coefficients }\end{array}$ & $\begin{array}{c}\text { Significance level } \\
\text { negative coefficients } \\
\text { by publication } \\
\text { number }\end{array}$ \\
\hline $\begin{array}{l}\text { High starting } \\
\text { point }\end{array}$ & 1 & 2 & 1 & 0 & & 2 & $23.1,23.2^{* * *}$ \\
\hline $\begin{array}{l}\text { Medium starting } \\
\text { point }\end{array}$ & 1 & 2 & 0 & 1 & 23.2 & 1 & 23.1 \\
\hline No. teenagers & 1 & 1 & 0 & 1 & 57.2 & 0 & \\
\hline $\begin{array}{l}\text { Perceived risk of } \\
\text { contracting } \\
\text { malaria }\end{array}$ & 1 & 2 & 0 & 2 & $9.1,9.2$ & 0 & \\
\hline Purchase of ITNs & 1 & 2 & 2 & 2 & $64.1 * * *, 64.2 * * *$ & 0 & \\
\hline $\begin{array}{l}\text { WTP for others } \\
\text { ITNs }\end{array}$ & 1 & 4 & 4 & 4 & $\begin{array}{l}90.1 * *, 90.2^{* *} \\
90.1 * * *, 90.2 *\end{array}$ & 0 & \\
\hline $\begin{array}{l}\text { Actual incidence } \\
\text { of other illnesses }\end{array}$ & 1 & 1 & 0 & 1 & 3.3 & 0 & \\
\hline $\begin{array}{l}\text { Community in } \\
\text { which } \\
\text { respondent and } \\
\text { his or her } \\
\text { household are } \\
\text { located }\end{array}$ & 1 & 2 & 1 & 1 & $66.2 * * *$ & 1 & 66.1 \\
\hline $\begin{array}{l}\text { Dependency } \\
\text { status of } \\
\text { household } \\
\text { members }\end{array}$ & 1 & 1 & 0 & 0 & & 1 & 89 \\
\hline $\begin{array}{l}\text { Dummy of } \\
\text { expenditure to } \\
\text { treat other } \\
\text { illnesses }\end{array}$ & 1 & 1 & 0 & 0 & & 1 & 3.3 \\
\hline $\begin{array}{l}\text { Healthcare } \\
\text { facility }\end{array}$ & 1 & 1 & 1 & 0 & & 1 & $89 * *$ \\
\hline $\begin{array}{l}\text { Household } \\
\text { children size } \\
\text { ( }<6 \text { years) }\end{array}$ & 1 & 2 & 2 & 2 & $8.1 * * *, 8.2 * *$ & 0 & \\
\hline $\begin{array}{l}\text { Household } \\
\text { female size }\end{array}$ & 1 & 2 & 0 & 2 & $8.1,8.2$ & 0 & \\
\hline $\begin{array}{l}\text { Households } \\
\text { teenagers size }\end{array}$ & 1 & 1 & 0 & 1 & 57.1 & 0 & \\
\hline $\begin{array}{l}\text { Individual 6- } \\
\text { month cash } \\
\text { expenditure, log } \\
10\end{array}$ & 1 & 2 & 0 & 2 & $8.1,8.2$ & 0 & \\
\hline $\begin{array}{l}\text { Individual 6- } \\
\text { month cash } \\
\text { income, log } 10\end{array}$ & 1 & 2 & 2 & 2 & $8.1 * *, 8.2 * *$ & 0 & \\
\hline $\begin{array}{l}\text { Household } \\
\text { means of } \\
\text { controlling the } \\
\text { disease vector }\end{array}$ & 1 & 1 & 1 & 1 & $105^{* *}$ & 0 & \\
\hline $\begin{array}{l}\text { Previous } \\
\text { participation in a } \\
\text { community } \\
\text { development } \\
\text { project }\end{array}$ & 1 & 1 & 1 & 1 & $105^{* *}$ & 0 & \\
\hline $\begin{array}{l}\text { Confidence in } \\
\text { the hypothetical } \\
\text { community trust } \\
\text { fund }\end{array}$ & 1 & 1 & 1 & 1 & $105 * *$ & 0 & \\
\hline
\end{tabular}


META-ANALYSIS OF WTP FOR MALARIA CONTROL

Appendix C. Continued.

\begin{tabular}{|c|c|c|c|c|c|c|c|}
\hline Variable & $\begin{array}{l}\text { No. } \\
\text { articles }\end{array}$ & $\begin{array}{l}\text { No. total } \\
\text { coefficients }\end{array}$ & $\begin{array}{l}\text { No. } \\
\text { significant } \\
\text { coefficients }\end{array}$ & $\begin{array}{c}\text { Total } \\
\text { positive } \\
\text { coefficients }\end{array}$ & $\begin{array}{c}\text { Significance level } \\
\text { positive coefficients } \\
\text { by publication } \\
\text { number }^{\mathrm{a}}\end{array}$ & $\begin{array}{c}\text { Total } \\
\text { negative } \\
\text { coefficients }\end{array}$ & $\begin{array}{l}\text { Significance level } \\
\text { negative coefficients } \\
\text { by publication } \\
\text { number }\end{array}$ \\
\hline $\begin{array}{l}\text { Currently using } \\
\text { public medical } \\
\text { facilities }\end{array}$ & 1 & 1 & 1 & 0 & & 1 & $111 * * *$ \\
\hline Stranger status & 1 & 1 & 1 & 1 & $111^{*}$ & 0 & \\
\hline Cost of spraying & 1 & 1 & 1 & 1 & $111 * * *$ & 0 & \\
\hline $\begin{array}{l}\text { Self-assessment } \\
\text { of own status } \\
\text { relatively to } \\
\text { others in the } \\
\text { society }\end{array}$ & 1 & 1 & 1 & 0 & & 1 & $111^{* * * *}$ \\
\hline $\begin{array}{l}\text { Log of cost of } \\
\text { spraying }\end{array}$ & 1 & 1 & 1 & 1 & $111^{* * * *}$ & 0 & \\
\hline $\begin{array}{l}\text { Log self- } \\
\text { assessment } \\
\text { rating }\end{array}$ & 1 & 1 & 1 & 0 & & 1 & $111 * * *$ \\
\hline $\begin{array}{l}\text { Log of total cost } \\
\text { of hospital } \\
\text { treatment }\end{array}$ & 1 & 1 & 1 & 1 & $111^{* * * *}$ & 0 & \\
\hline $\begin{array}{l}\text { Use of } \\
\text { community } \\
\text { health workers }\end{array}$ & 1 & 2 & 1 & 1 & 119.1 & 1 & $119.2 * * *$ \\
\hline $\begin{array}{l}\text { Confidence in } \\
\text { the hypothetical } \\
\text { trust fund }\end{array}$ & 1 & 3 & 3 & 3 & $\begin{array}{l}126.1 * *, 126.2 * * . \\
126.3^{* *}\end{array}$ & 0 & \\
\hline $\begin{array}{l}\text { Hospitalization } \\
\text { for malaria } \\
\text { within last } \\
12 \text { months }\end{array}$ & 1 & 3 & 1 & 1 & $131.2^{* *}$ & 2 & $131.1,131.3$ \\
\hline Have children & 1 & 3 & 0 & 2 & $131.2,131.3$ & 1 & 131.1 \\
\hline $\begin{array}{l}\text { Have health } \\
\text { insurance }\end{array}$ & 1 & 3 & 0 & 2 & $131.1,131.3$ & 1 & 131.2 \\
\hline City of residence & 1 & 3 & 0 & 1 & 131.2 & 2 & $131.1,131.3$ \\
\hline
\end{tabular}

Significance of parameters: $* \leq 0.10 ; * * \leq 0.05 ; * * * \leq 0.01$.

No. articles

Total number of publications reporting this variable

No. total coefficients

Total number of coefficients reported in all different articles

Total positive coefficients

Significance level positive coefficients Specification of the significance level from positive coefficients

Total negative coefficients Total number of negative coefficients reported by all articles

Significance level negative coefficients Specification of the significance level from negative coefficients

${ }^{a}$ Numbers used in this column refer to a concrete paper. The repetition of these numbers using a dot and adding a second number try to reflect the appearance order of these coefficients in the paper. For instance, the positive coefficients related to gender withdrawed from paper 66 are two: 66.1 (1st coefficient) and 66.2 (2nd coefficient). These coefficients are ordered according to the appearing order.

\section{CONFLICT OF INTEREST}

The authors declare no conflict of interest.

\section{ACKNOWLEDGEMENTS}

The authors are grateful to Dr Laura Vallejo-Torres, Professor Janet Peacock, Dr Zoe Philips and Dr Nana Anokye for helpful comments on previous drafts of articles. They gratefully acknowledge partial funding from Agencia de Gestio d'Ajuts Universitaris i de Recerca (AGAUR) for supporting a student placement from which this work developed. The remaining funding was supported by the Brunel University. They also thank the two anonymous reviewers for useful comments and questions. 


\section{REFERENCES}

(*References included in the meta-analysis)

*Alaii JA, Vanden Borne HW, Kachur SP, Mwenesi H, Vulule JM, Hawley WA, Meltzer MI, Nahlen BL, Phillips-Howard PA. 2003. Perceptions of bed nets and malaria prevention before and after a randomized controlled trial of premethrintreated bed nets in western Kenya. American Journal of Tropical Medicine and Hygiene 68(4): 142-148.

*Ankomah-Asante F, Asenso-Okyere K. 2003. Economic Burden of Malaria in Ghana. [online]. A technical report submitted to the World Health Organization (WHO), African Regional Office (AFRO). Available from: http://www.who.int/ countries/gha/publications/Economic_Burden_of_Malaria_in_Ghana_Final_Report_Nov03.pdf\#search=\%22Economic $\% 20$ Burden $\% 20$ of\%20Malaria\%20in\%20Ghana\%22 [July 2005].

*Ankomah-Asante F, Asenso-Okyere K, Kusi A. 2005. The economic impact of the burden of malaria in Ghana. Technical Publication 66. Institute of Statistical, Social and Economic Research, University of Ghana, Legon.

*Asafu-Adjaye J, Dzator J. 2003. Willingness to pay for malaria insurance: a case study of households in Ghana using the contingent valuation method. Economic Analysis and Policy 33(1): 31-47.

*Attanayake N. n.d. An assessment of the willingness to pay for malaria control measures in Sri Lanka. Sri Lanka: University of Colombo. Projects on malaria supported by the TDR, WHO/HQ.

Bateman I, Jones A, Nishikawa N, Brouwer R. 2000. GEC-2000-25: Benefits Transfer in Theory and Practice: A Review. Available from: http://www.cserge.ac.uk/publications/author/43 Download: gec_2000_25.pdf (455.48 KB)

Bateman IJ, Carson RT, Day B, Hanemann M, Hanley W, Hett T, Jones-Lee M, Loones G, Mourato S, Ozdemiroglu E, Pearce DW, Sugden R, Suranson J. 2002. Economic Evaluation with Stated Preference Techniques: a Manual. Edward Elgar: Cheltenham, UK.

*Bhatia MR. 2005. From evidence to calibration for starting point bias: willingness to pay for treated mosquito nets in Gujarat, India. Applied Economics 37: 1-7.

*Bhatia MR, Fox-Rushby JA. 2002. Willingness to pay for treated mosquito nets in Surat, India: the design and descriptive analysis of a household survey. Health Policy and Planning 17(4): 402-411.

Breman J, Mills A, Snow R, Mulligan J, Lengeler C, Mendis K, Sharp B, Morel C, Marchesini P, White N, Steketee N, Doumbo O. 2006. Conquering malaria. In Disease Control Priorities in Developing Countries (2nd edn), Jamison et al. (eds). Oxford University Press: New York.

Brouwer R, Bateman IJ. 2005. Benefits transfer of willingness to pay estimates and functions for health-risk reductions: a cross-country study. Journal of Health Economics 24: 591-611.

Brouwer R, Langford IH, Bateman JJ, Turner RK. 1999. A meta-analysis of wetland contingent valuation studies. Regional Environmental Change 1(1): 47-57.

*Chase C, Sicuri E, Sacoor C, Nhalungo D, Nhacolo A, Alonso PL, Menéndez C. 2009. Determinants of household demand for bed nets in a rural area of southern Mozambique. Malaria Journal 8: 132-142.

*Cho-Min-Naing, Lertmaharit S, Kamol-Ratanakul P, Saul AJ. 2000. Ex post and Ex ante WTP for the ICT Malaria pf/pv Test Kit in Myanmar. Southeast Asian Journal of Tropical Medicine and Public Health 31(1): 104-111.

*Cropper ML, Haile M, Lampietti JA, Poulos C, Whittington D. 2000. The value of preventing malaria in Tembien, Ethiopia. Policy research Working Papers 2273. World Bank.

*Cropper ML, Haile M, Lampietti JA, Poulos C, Whittington D. 2004. The demand for a malaria vaccine: evidence from Ethiopia. Journal of Development Economics 75: 303-318.

DerSimonian R, Laird N. 1986. Meta-Analysis in Clinical Trials. Controlled Clinical Trials 7(3): 177-188.

*Dgedge MDC. 2000. Implementation of an insecticide treated bednet programme for malaria prevention through the primary health care system in Mozambique: Socioeconomic factors associated with sustainability and equity. PhD dissertation, London School of Hygiene and Tropical Medicine.

Diener A, O'Brien B, Gafni A. 1998. Health Care contingent valuation studies: a review and classification of the literature. Health Economics 7: 313-326.

Engel S. 2002. Benefit function transfer versus meta-analysis as policy tool: a comparison. In Comparative Environmental Economic Assessment, Florax RJGM, Nijkamp P, Cheltenham KGW (eds). Edward Elgar: UK and Northampton, MA.

*Fonta WM, Ichoku HE, Kabubo-Mariara J. 2010. The effect of protest zeros on estimates of willingness to pay in healthcare contingent valuation analysis. Applied Health Economics and Health Policy 8(4): 225-237.

*Gunasekaran K, Sahu SS, Vijayakumar KN, Jambulingam P. 2009. Acceptability, willing to purchase and use long lasting insecticide treated mosquito nets in Orissa State, India. Acta Tropica 112: 149-155.

*Guyatt HL, Ochola SA, Snow RW. 2002. Too poor to pay: charging for insecticide-treated bednets in highland Kenya. Tropical Medicine and International Health 7(10): 846-850.

Hanley N, Colombo S, Kriström B, Watson F. 2009. Accounting for Negative, Zero and Positive Willingness to Pay for Landscape Change in a National Park, Journal of Agricultural Economics 60(1): 1-16. 
*Hoffmann V. 2009. Do free goods stick to poor households?experimental evidence on insecticide treated bednets. World Development 37(3): 607-617.

*Jima D, Tesfaye G, Deressa W, Woyessa A, Kebede D, Alamirew D. 2005. Baseline survey for the implementation of insecticide treated mosquito nets in Malaria control in Ethiopia. The Ethiopian Journal of Health Development 19(1): 16-23.

*Jimoh A, Sofola O, Petu A, Okorosobo T. 2007. Quantifying the economic burden of malaria in Nigeria using the willingness to pay approach. Cost Effectiveness and Resource Allocation 5(6): 1-8.

Johnston RJ, Besedin EY, Iovanna R et al. 2005. Systematic variation in willingness to pay for aquatic resource improvements and implications for benefit transfer: a meta-analysis. Canadian Journal of Agricultural Economics 53(2-3): 221-248.

*Juana JS, Narayana N, Mupimpila C. 2004. Estimating household expenditure on malaria interventions in western sierra leone: a contingent valuation approach. International Journal of Environment and Development 1(1): 67-81.

Kamya M, Bakyaita N, Talisuna A, Were W, Staedke S. 2002. Increasing antimalarial drug resistance in Uganda and revision of the national drug policy. Tropical Medicine and International Health 7(12): 1031-1041.

*Kilian AHD, Tindyebwa D, Gülck T, Byamukama W, Rubaale T, Kabagambe G, Korte R. 2003. Attitude of women in western Uganda towards pre-packed, unit-dosed malaria treatment for children. Tropical Medicine and International Health 8(5): 431-438.

Korenromp E. 2005. Malaria Incidence Estimates at country level for the year 2004 - proposed estimates and draft report. Switzerland: World Health Organization. Available from: http://www.who.int/malaria/docs/incidence_estimations2. pdf\#search $=\% 22$ Malaria $\% 20$ Incidence $\% 20$ Estimates $\% 20$ at $\% 20$ country $\% 20$ level $\% 20$ for $\% 20$ the $\% 20$ year $\% 202004 \%$ $20 \%$ E2\%80\%93\%20proposed $\% 20$ estimates $\% 20$ and $\% 20$ draft $\% 20$ report $\% 22$ [August 2006].

*Lampietti J. 1999. Do husbands and wives make the same choices? Evidence from Northern Ethiopia. Economics Letters 62(2): 253-260.

*Lampietti J, Poulos C, Cropper ML, Mitiku H, Whittington D. 1999. Gender and preferences for malaria prevention in Tigray, Ethiopia. Working Paper Series no 3, Policy Research Report on Gender and Development.

*Legesse Y, Tegegn A, Belachew T, Tushune K. 2007. Households willingness to pay for long-lasting insecticide treated nets in three urban communities of Assosa zone, western Ethiopia. Ethiopian Medical Journal 45(4): 353 -362.

*Lin K, Aung S, Lwin S, Min H, Aye NN, Webber R. 2000. Promotion of insecticide-treated mosquito nets in Myanmar. The Southeast Asian Journal of Tropical Medicine and Public Health 31(3): 444-447.

*MacCormack CP, Snow RW, Greenwood BM. 1989. Use of insecticide-impregnated bed nets in Gambian primary health care: economic aspects. Bulletin of the World Health Organization 67(2): 209-214.

Malaney P, Spielman A, Sachs J. 2005. The Malaria Gap. Post-autistic Economics Review 31(1).United States. http://www. paecon.net/PAEReview/issue31/MalaneySpielmanSachs31.htm [3 August 2006].

* Masiye F, Rehnberg C. 2005. The economic value of an improved malaria treatment programme in Zambia: results from a contingent valuation survey. Malaria Journal 4(60): 1-30.

*Mills A, Fox-Rushby J, Aikins M, D’Alessandro U, Cham K, Greenwood B. 1994. Financing mechanisms for village activities in The Gambia and their implications for financing insecticide for bednet impregnation. The Journal of Tropical Medicine and Hygiene 97: 325-332.

Mills A, Lubell Y, Hanson K. 2008. Malaria eradication: the economic, financial and institutional challenge. Malaria Journal, 74(Supp 1): S11.

Mitchel RC, Carson RT. 1993. Using surveys to value public goods: the contingent valuation method. The Johns Hopkins University Press: Washington, DC.

Moeltner K, Boyle KJ, Paterson RW. 2006. Meta-Analysis and Benefit Transfer for Resource Valuation - Addressing Classical Challenges with Bayesian Modeling, Draft, University of Nevada. Available from: http://agecon.tamu.edu/ research/pdf/moeltnerseminar.pdf\#search=\%22meta-analysus\%20or\%20benefit\%20transfer\%22 [20 August 2006]

*Mujinja PGM. 2006. Exploring determinants of consumer preferences and willingness-to-pay for insecticides treated bednets before intervention in a poor rural Tanzania. East African Journal of Public Health 3(1): 17-22.

*Mujinja PGM, Makwaya CK, Sauerborn R. 2004. Gender and willingness to pay for insecticides treated bed nets in a poor rural area in Tanzania. East African Medical Journal 81(12): 641-648.

Mulligan JA, Fox-Rushby J, Adam T, Johns B, Mills A. 2003. Unit costs of health care inputs in low and middle income regions. Working Paper No. 9, Disease Control Priorities Project, London. Available from: http://www.fic.nih.gov/dcpp/ wps/wp9.pdf [10 August 2006].

Mulligan J-A, Mandike R, Palmer N, Williams H, Abdulla S, Bloland P, Mills A. 2006. The costs of changing national policy: lessons from malaria treatment policy guidelines in Tanzania. Tropical Medicine \& International Health 11: 452-461.

*Munpuibeyi Fonta W, Ichoku HE, Ogujiuba KK. 2010. Estimating willingness to pay with the stochastic payment card design: further evidence from rural Cameroon. Environment, Development and Sustainability 12: 179-193.

OECD. 2002. Handbook of Biodiversity Valuation: A Guide for Policy Makers. OECD Publications: Paris, France.

*Ofiara DD, Allison JR. 1986. On assessing the benefits of public mosquito control practices. Journal of the American Mosquito Control Association 2(3): 280-288. 
*Okrah J, Traore C, Pale A, Sommerfield J, Muller O. 2002. Community factors associated with malaria prevention by mosquito nets: an exploratory study in rural Burkina Faso. Tropical Medicine and International Health 7(3): 240-248.

Olsen JA, Smith RD. 2001. Theory versus practice: a review of willingness-to-pay in health and health care. Health Economics 10: 39-52.

*Onwujekwe O. 2001. Searching for a better willingness to pay elicitation method in rural Nigeria: The binary question with follow-up method versus the bidding game technique. Health Economics 10(2): 147-158.

*Onwujekwe O. 2004. Criterion and content validity of a novel structured haggling contingent valuation question format versus the bidding game and binary with follow-up format. Social Science and Medicine 58: 525-537.

*Onwujekwe O, Nwagbo D. 2002. Investigating starting-point bias: a survey of willingness to pay for insecticide-treated nets. Social Science and Medicine 55(12): 2121-2130.

*Onwujekwe O, Uzochukwu B. 2004. Stated and actual altruistic willingness to pay for insecticide-treated nets in Nigeria: validity of open-ended and binary with follow-up questions. Health Economics 13: 477-492.

*Onwujekwe O, Shu E, Chima R, Onyido A, Okonkwo P. 2000. Willingness to pay for the retreatment of mosquito nets with insecticide in four communities of south-eastern Nigeria. Tropical Medicine \& International Health 5(5): 370-376.

*Onwujekwe O, Chima R, Shu E, Nwagbo D, Okonkwo P. 2001. Hypothetical and actual willingness to pay for insecticidetreated nets in five Nigerian communities. Tropical and International Health 6(7): 545-553.

*Onwujekwe O, Chima R, Shu E, Nwagbo D, Akpala C, Okonkwo P. 2002. Altruistic willingness to pay in communitybased sales of insecticide-treated nets exists in Nigeria. Social Science and Medicine 54: 519-527.

*Onwujekwe O, Fox-Rushby J, Hanson K. 2004a. Valuing the Benefit of a Health Intervention Using Three Different Approaches to Contingent Valuation: Re-treatment of Mosquito Bed-nets in Nigeria. Journal of Health Services Research and Policy 9(2): 67-75.

*Onwujekwe O, Hanson K, Fox-Rushby J. 2004b. Inequalities in purchase of mosquito nets and willingness to pay for insecticide-treated nets in Nigeria: challenges for malaria control interventions. Malaria Journal 3(6): 1-8. Available from: http://www.pubmedcentral.nih.gov/picrender.fcgi?artid=395839\&blobtype=pdf [10 November 2006]

*Onwujekwe O, Uzochukwu B, Shu E, Ibeh C, Okonkwo P. 2004c. Is combination therapy for malaria based on user-fees worthwhile and equitable to consumers? Assessment of costs and willingness to pay in Southeast Nigeria. Acta Tropica 91: 101-115.

*Onwujekwe O, Fox-Rushby J, Hanson K. 2005a. Inter-rater and test-retest reliability of three contingent valuation question formats in south-east Nigeria. Health Economics 14: 529-536.

*Onwujekwe O, Hanson K, Fox-Rushby J. 2005b. Do divergences between stated and actual willingness to pay signify the existence of bias in contingent valuation surveys? Social Science and Medicine 60: 525-536.

*Onwujekwe O, Malik E, Hassan Mustafa S, Mnzava A. 2005c. Socio-economic inequity in demand for insecticidetreated nets, in-door residual house spraying, larviciding and fogging in Sudan. Malaria Journal 4(62): 1-26.

*Onwujekwe O, Ojukwu J, Ezumah N, Uzochukwu B, Dike N, Soludo E. 2006. Socio-economic differences in preferences and willingness to pay for different providers of malaria treatment in southeast Nigeria. American Journal of Tropical Medicine and Hygiene 75(3): 421-429.

*Onwujekwe O, Ojukwu J, Shu E, Uzochukwu B. 2007. Inequities in valuation of benefits, choice of drugs, and mode of payment for malaria treatment services provided by community Health workers in Nigeria. American Journal of Tropical Medicine 77(1): 16-21.

Pai M, Flores LL, Hubbard A, Riley LW, Colford JM. 2003. Quality assessment in meta-analyses of diagnostic studies: what difference does email contact with authors make? XI Cochrane Colloquium, Barcelona, Spain.

Perera R, Heneghan C. 2008. Interpreting meta-analysis in systematic reviews. Evidence-Based Medicine 13(3): 67-69.

Petitti DB. 2000. Meta-analysis, Decision Analysis and Cost-Effectiveness analysis. Methods for quantitative synthesis in medicine (2nd edn). Oxford University Press: Oxford.

*Poulos C. 2000. Improving the reliability of the benefit transfer method: a new approach and an application to malaria prevention. Center for Environmental and Resource Economic Policy. North Carolina State University. Available from: http://www.cerge.cuni.cz/pdf/events/papers/010301_t.pdf\#search=\%22Improving\%20the\%20reliability\%20of\%20the $\% 20$ benefit $\% 20$ transfer $\% 20$ method $\% 3$ A $\% 20$ a $\% 20$ new $\% 20$ approach $\% 20$ and $\% 20$ an $\% 20$ application $\% 20$ to $\% 20 \mathrm{malaria}$ $\% 20$ prevention $\%$ E2\%80\%99\%22 [July 2005].

*Prabhu VS. 2010. Tests of intrahousehold resource allocation using a CV framework: a comparison of husbands' and wives' separate and joint WTP in the slums of Navi-Mumbai, India. World Development 38(4): 606-619.

*Rennie W, Lugo L, Rosser E, Harvey SA. 2009. Willingness to use and pay for a new diagnostic test for malaria in children under 5: Results from Benin, Peru and Tanzania. Center for Human Services: Bethesda, MD.

Roll Back Malaria Partnership. 2008. The Global Malaria Action Plan For A Malaria Free World. Available from: http:// www.rollbackmalaria.org/gmap/gmap.pdf

Rosenberger RS, Loomis JB. 2000. Panel stratification in meta-analysis of economic studies: An investigation of its effects in the recreation valuation literature. Journal of Agricultural and Applied Economics 32(3): 459-470. 
*Sanjana P, Barcus MJ, Bangs MJ, Ompusunggu S, Elyazar I, Marwoto H, Tuti S, Sururi M, Tjokrosonto S, Baird JK. 2006. Survey of community knowledge, attitudes, and practices during a malaria epidemic in central Java, Indonesia. The American Journal of Tropical Medicine and Hygiene 75(5): 783-789.

*Sauerborn R, Gbangou A, Dong H, Przyborski JM, Lanzer M. 2005. Willingness to pay for hypothetical malaria vaccines in rural Burkina Faso. Scandinavian Journal of Public Health 33: 146-150.

*Saulo EC, Forsberg BC, Premji Z, Montgomery SM, Björkman A. 2008. Willingness and ability to pay for artemisinbased combination therapy in rural Tanzania. Malaria Journal 7: 227-237.

Shrestha RK. 2001. Testing a meta-analysis model for benefit transfer in International Outdoor Recreation. Ecological Economics 39: 67-83.

Stata Corporation. 2007. Stata Reference Manual. Release 10.0. College Station, TX.

Strazzera E, Scarpa R, Calia P, Garrod G, Willis K. 2003. Modelling zero values and protest responses in contingent valuation surveys Applied Economics 35(2): 133-138.

Sutton AJ, Higgins JPT. 2008. Recent developments in meta-analysis. Statistics in Medicine 27: 625-650.

Sutton AJ, Abrams KR, Jones DR, Sheldon TA, Song F. 2004. Methods for Meta-Analysis in Medical Research. Wiley: England, UK.

*Udezi WA, Odianose Usifoh C, Oluwatosin Ihimekpen O. 2010. Willingness to pay for three hypothetical malaria vaccines in Nigeria. Clinical Therapeutics 32(8): 1533-1544.

*Uzochukwu BSC, Onwujekwe OE, Uguru NP, Ughasoro MD, Ezeoke OP. 2010. Willingness to pay for rapid diagnostic tests for the diagnosis and treatment of malaria in southeast Nigeria: ex post and ex ante. International Journal for Equity in Health 9: 1-8.

Van Houtven G. 2008. Methods for the meta-analysis of willingness-to-pay data. PharmacoEconomics 26(11): 901-910.

Van Houtven G, Powers J, Pattanayake S. 2007. Valuing water quality improvements in the United States using meta-analysis: Is the glass half-full or half-empty for national policy analysis? Resource and Energy Economics 29: 206-228.

*Weaver M, Kornfield R, Chapko M, Blewane C, Ndamobissi R, Sathe A, Ngueretia L-P. 1993. Estimating the willingness to pay for quality of care: comparison of contingent valuation and two-step health expenditure methods. Small applied research paper no. 9. Health Services Division, Office of Health, Agency for International Development. Available from: http://www.phrplus.org/Pubs/hfssar9.pdf\#search=\%22Estimating\%20the \%20willingness $\% 20$ to $\% 20$ pay $\% 20$ for $\% 20$ quality $\% 20$ of $\% 20$ care $\% 3$ A $\% 20$ comparison $\% 20$ of $\% 20$ contingent $\% 20$ valuation $\% 20$ and $\% 20$ two-step $\% 20$ health $\% 20$ expenditure $\% 20$ methods $\% 22$ [July 2005].

*Weaver M, Ndamobissi R, Kornfield R, Blewane C, Sathe A, Chapko M, Bendje N, Nguembi E, Senwara-Defiobona J. 1996. Willingness to pay for child survival: results of a national survey in central African republic. Social Science and Medicine 43(6): 985-998.

*Whittington D, Castelar-Pinheiro A, Cropper M. 2003. The economic benefits of malaria prevention: a contingent valuation study in Marracuene, Mozambique. Journal of Health and Population in Developing Countries 15(27): 1-27.

Wilson MA, Hoehn JP. 2006. Valuing environmental goods and services using benefit transfer: The state-of-the art and science. Ecological Economics 60(2): 335-342.

*Wiseman V, Onwujekwe O, Matovu F, Mutabingwa TK, Whitty CJM. 2005. Differences in willingness to pay for artemisin-based combinations or monotherapy: experiences from the United Republic of Tanzania. Bulletin of the World Organization 83(11): 845-852.

Wong MCCJ, Wong TK. 2007. Effects of treatments for symptoms of painful diabetic neuropathy: systematic review. BMJ 335(7610): 87.

World Bank, International Monetary Fund. 2005. World Economic Database. Washington, DC, USA. Available from: http://www.imf.org/external/pubs/ft/weo/2005/02/data/index.htm [July 2005].

World Bank, UNICEF. 2005. Malaria Report. Washington, D.C. USA.

Yeung R, Smith R, Ho L-M, Johnston J, Leung G. 2006. Empirial implications of response acquiescence in discrete-choice contingent valuation. Health Economics 15: 1077-1089. 